\title{
'Doing' masculinity: Enactments of masculinity and manliness in drawings of rifles and bayonets in the Australian Imperial Force, 1914-1918
}

\section{EMILY GALLAGHER}

\section{Abstract}

During the First World War, a number of Australian soldiers used drawing as a way to communicate and record their experiences of active service. As a neglected body of archival material, these drawings offer unique insights into how men of the Australian Imperial Force (AIF) understood and conceptualised their masculinity and manliness while abroad. In this study, I analyse depictions of rifles and bayonets in 91 drawings by Australian soldiers to explore the ways in which a number of the men of the AIF enacted militaristic and 'working-man' masculinity. I argue that while both of these masculinities existed concurrently in soldiers' drawings, the bayonet was commonly used to further militaristic virtues of aggression and martial prowess, whereas the rifle tended to reassert the pre-war ideals of the working man. For the first time, Australian soldiers' drawings fall under the gaze of the historian and they present a nuanced, sometimes contradictory, understanding of how soldiers imagined and enacted their own masculinity and manliness at war.

Externalisation: Give external form or existence to; express (a thought or feeling) in words or actions; project (a mental image or process) on to a figure outside oneself. ${ }^{1}$

1 'Externalise', in Oxford Dictionary of English, ed. Angus Stevenson, en.oxforddictionaries.com/definition/ externalize. 
Drawing is a process of externalisation..$^{2}$ It is, amongst other things, a medium that enables a person to project perceptions of the self in a graphic form. ${ }^{3}$ During the First World War, a number of Australian soldiers used drawing as a way to negotiate the visual-spatial reality of the wartime landscape, and position themselves and others within it. Though seldom examined as a body of primary evidence in its own right, these drawings offer historians a unique lens onto the self-images and attitudes that soldiers held of themselves during their military service. Crucially, they provide valuable insight into how a number of these men understood and conceptualised their own manliness and masculinity. Focusing on the relationship between drawing, manliness and masculinity, this article examines the depiction of rifles and bayonets in 91 drawings by men of the AIF between 1914 and 1918 to explore the ways in which these two weapons were used to enact militaristic and 'working-man' masculinities. I argue that while both of these masculinities existed concurrently in soldiers' drawings, depictions of the bayonet were commonly associated with the militaristic virtues of aggression and martial prowess, while rifles reasserted the pre-war ideals of the working man, such as hard work and resilience.

This article is divided into three parts. The first part provides an overview of the existing historiography of militaristic and working-man masculinity. The second part discusses the origins and composition of the soldiers' drawings under examination. The third part analyses how the rifle and bayonet were used to enact militaristic and working-man masculinity. As this article demonstrates, both weapons played an important role in the way a number of soldier-artists externalised their masculinity and advanced their manliness.

\section{Militaristic and working man masculinity}

'Manliness' or 'manly' refer to the ideals of being male, such as courage and endurance, and should not be confused with 'masculinity' or 'masculine', which refer to the characteristics that contemporaries believed were biologically attributed to being male. ${ }^{4}$ In other words, masculinity is generally considered inherent in a man's sex, but it is only through his behaviour that he can achieve some level

2 Barbara Tversky, 'What Does Drawing Reveal about Thinking?', in Visual and Spatial Reasoning in Design, ed. J. S. Gero and B. Tversky (Sydney: Key Center of Design Computing and Cognition, 1999); Gabriela Goldschmidt, 'Design Representation: Private Process, Public Image', in Design Representation, ed. Gabriela Goldschmidt and William L. Porter (London: Springer-Verlag, 2004).

3 Patrick Maynard, Barbara Tversky and David Rosand argue that drawings are 'revelatory', 'projection[s] of the self' that make 'oneself understood'. See Patrick Maynard, 'Review', in Drawing Acts: Studies in Graphic Expression and Representation, ed. David Rosand (Cambridge: Cambridge University Press, 2005), 83; David Rosand, Drawing Acts: Studies in Graphic Expression and Representation (Cambridge: Cambridge University Press, 2002), xxii, 16; Robert Fawcett, On the Art of Drawing: An Informal Textbook with Illustrations by the Author (New York: WatsonGuptill Publications, 1977), 71.

4 Martin Crotty, Making the Australian Male: Middle-Class Masculinity 1870-1920 (Melbourne: Melbourne University Press, 2001), 8. 
of manliness. Since the 1980s, the historiography of manliness and masculinity in the AIF has been fraught with disagreement. ${ }^{5}$ Though historians have applauded R.W. Connell's concept of hegemonic masculinity and the notion that multiple masculinities can coexist in the same historical context, scholars have continued to dispute which masculinity was dominant and, when performed, best displayed a man's manliness. ${ }^{6}$ In the Australian historiography, two schools of thought have dominated attempts to determine the virtues that were most commonly associated with the ideal man of the AIF.

The first, led by Martin Crotty, and furthered by scholars such as Henry Reynolds, Bryan Dywer and Stephen Garton, has asserted that militaristic and imperial virtues were the most desirable traits for the men of the AIF.7 They argue that concerns over racial degeneracy in the colonies and growing fears of an invasion from European and Asian powers in the late eighteenth and early twentieth century led to the glorification of the soldier and the establishment of militarism as the hegemonic masculinity. Using adventure stories for boys as evidence for popular imaginings of masculinity, Richard Phillips and Crotty have argued that, over a decade before the war, the military man had 'supplanted settler man and domestic man'. ${ }^{8}$ While Crotty acknowledges that '[o]bedience, discipline, loyalty, devotion, physical strength, readiness to fight for a cause and adventurousness' - values all associated with militaristic masculinity-were sometimes threatened by the carnage of the First World War, he maintains that these values remained distinctively masculine, and when performed were undeniable evidence of a man's manliness. ${ }^{9}$ Though all of these scholars recognise that other masculinities coexisted, they maintain that none could claim the same level of manliness as the soldier, especially the uniquely Australian bushman soldier. ${ }^{10}$

\footnotetext{
5 The study of masculinity and manliness - and masculinity as defined by war-first came to fruition in the late 1980 s, before flourishing in the 1990s and early 2000 s.

6 The concept of 'hegemonic masculinity' was formulated by R. W. Connell in her book Gender and Power, published in 1987. She argued that there is no single, unchanging form of masculinity, but rather that there is a 'hegemonic masculinity', which Connell saw as a culturally dominant form or idealisation of masculinity that prevails over other forms. See R. W. Connell, Gender and Power: Society, the Person, and Sexual Politics (Cambridge: Polity Press \& B. Blackwell, 1987).

7 Bryan Dwyer, 'Place and Masculinity in the Anzac Legend', Journal for the Association of the Study of Australian Literature 4 (1997); Stephen Garton, 'War and Masculinity in Twentieth-Century Australia', Journal of Australian Studies 22, no. 56 (1998); Henry Reynolds, 'Are nations really made in war?', in What's Wrong with ANZAC? The Militarisation of Australian History, ed. Marilyn Lake and Henry Reynolds (Sydney: University of New South Wales, 2010); Rachel Woodward, 'Warrior Heroes and Little Green Men: Soldiers, Military Training, and the Construction of Rural Masculinities', Rural Sociological Society 65, no. 4 (2000).

8 Martin Crotty, 'Heroes of Australia: Race, Nation and Masculinity in Australian Boys' Adventure Stories, 1875-1920', Bulletin (Olive Pink Society) 11, no. 1-2 (1999), 26; Richard Phillips, Mapping Men and Empire: A Geography of Adventure (London: Routledge, 1997), 70, ch. 4.

9 Crotty, Making the Australian Male, 230.

10 Bill Gammage, 'Anzac', in Intruders in the Bush: The Australian Quest for Identity, ed. John Carroll (Oxford: Oxford University Press, 1992), 63.
} 
In opposition, a competing argument has emerged that contends that nineteenthand early twentieth-century notions of manliness were not completely supplanted by athleticism and militarism. Rather, pre-existing perceptions of the working man and the role of men as breadwinners from the Victorian and Edwardian eras were still powerful frameworks in furthering a man's manliness and legitimising his masculinity during the years of 1914 and $1918 .{ }^{11}$ In his book Anzac Labour, Nathan Wise argues that before enlistment 'work formed a central part of men's lives' and acceptance 'into the military did not end the pursuit of manliness'. ${ }^{12}$ Analysing the diaries and letters of AIF soldiers, Wise claims that men saw hard work, particularly manual labour, as a distinctively manly act. ${ }^{13}$ Marilyn Lake agrees, arguing that the working man was central to representations of manliness in the national cultural politics of the early twentieth century. ${ }^{14}$ Russel Ward and Kate Murphy make similar assertions, insisting that pastoral ideals, settlement imperatives and labour tropes were at the forefront of masculinist constructions during and after the war. ${ }^{15}$ With varying degrees of restraint, these scholars have argued that Australian soldiers primarily understood their military service as a form of employment, asserting that hard work and financial stability were more highly valued than proficiency of arms or physical supremacy.

The scholarship being mounted in the debate over whether militaristic or workingman ideals dominated soldiers' perceptions of their own manliness, and the extent to which men enacted these masculinities throughout the war, has cultivated a divide in Australian historiography. Instead of understanding how these two masculinities interacted, historians have persisted in debating their nature and hegemony. In this article, I move beyond this division. Rather than deliberating upon the extent or dominance of militaristic or 'working-man' masculinity—or any other masculinity - this study focuses on their interaction and representation in soldiers' visual culture between 1914 and 1918. By understanding drawing as a medium for men to externalise their own masculinity, I examine how a number of men of the AIF enacted militaristic and 'working-man' masculinity in rifles and bayonets. It is important to note that the focus on these two masculinities does not attempt to discredit or dismiss the coexistence of alternative masculinities. Nor do I suggest that weapons were the only aspects of visual culture that enacted

11 Marcella Sutcliffe has produced a convincing case for the existence of other Edwardian values in British and Australian armies by tracing popular and soldiers' attitudes towards books. See Marcella P. Sutcliffe, 'Reading at the Front: Books and Soldiers in the First World War', International Journal of the History of Education 52, no. 1-2 (2016). 12 Nathan Wise, Anzac Labour: Workplace Cultures in the Australian Imperial Force during the First World War (New York: Palgrave Macmillan, 2014), 69.

13 Ibid., 68-71.

14 Marilyn Lake, 'Translating Needs into Rights: The Discursive Imperative of the Australian White Man, 190130', in Masculinities in Politics and War: Gendering Modern History, ed. Stefan Dudink, Karen Hagemann and Josh Tosh (Manchester: Manchester United Press, 2004).

15 Russel Ward, 'The Ethos and Influence of the Australian Pastoral Worker', PhD Thesis (Canberra: The Australian National University, 1956); Kate Murphy, 'The "Most Dependable Element of any Country's Manhood": Masculinity and Rurality in the Great War and its Aftermath', History Australia 5, no. 3 (2008), 72.5. 
soldiers' masculinity or were used to express manly ideals, or that their depiction is necessarily representative of trends in written and oral accounts. Alongside offering a more productive evidence-based approach to examining masculinity and manliness during the First World War, this study draws attention to a neglected body of primary evidence and highlights the value of adopting a narrow lens to the study of gender, war and culture.

\section{The drawings}

The drawings examined in this article were sourced from the State Library of New South Wales (SLNSW), Australian War Memorial (AWM), State Library of Victoria, troop periodicals and compiled publications during and after the war. Over 443 diaries, letters, archived art material and two trench newspapers (The Dinkum Oil and Kia Ora Coo-ee) were viewed to complete this analysis, of which 91 drawings were explicitly relevant for this study. This analysis does not claim to be representative of the perceptions or attitudes of all soldiers in the AIF. References to 'soldiers' and 'soldiers' drawings' only refer to the drawings included in this article. Drawings in digitised, private, published and art collections were identified using five predetermined filter terms: 'rifles', 'soldiers', 'weapons', 'trench' and 'bayonets'. That said, broader consideration has been given to drawings that did not include weapons.

The 91 drawings in this article are attributed to 26 soldiers who served in divisional signal companies, field artillery brigades, medical corps, infantry battalions and light horse regiments. Over half of these soldiers worked as clerks and artists before the war, while the other half were employed as tradesmen, labourers and trained professionals. Seven of the soldier artists had their work included in The Anzac Book or trench periodicals, and three published their sketches in independent compilations after the war. ${ }^{16}$ The drawings under study predominately used pencil or ink-based media and tend to be a product of observed experience rather than metaphorical representations. In fact, with the exception of James Marshall's drawing 'The first night in ...', none of the drawings in this article feature the rifle or bayonet in a metaphorical or imaginative manner (Fig. 7). ${ }^{17}$ Though they encompass a variety of forms, including portraits, silhouettes, cartoons, sketching, landscape and figure drawing, most maintain an attempt to depict weaponry and the human figure accurately, making the patterns and trends in the drawings by the men of the AIF coherent and comparable.

16 Soldier artists who published their work in trench periodicals include Sergeant Charles H. Gould, Gunner William K. Eltham, Sergeant Francis P. Hewkley, Sapper Thomas H. Ivers, Private Benjamin H. E. Price and Gunner Arthur H. Scott. Soldiers who published their drawings in independent compilations include Sergeant Penleigh Boyd, Sergeant Frederick H. Knowles and Private Ellis Silas.

17 James J. Marshall, '13. “The first night in ...”, in Sketches of the Somme, 1917, SLNSW, PXA 381 (v. 2). 


\section{Rifles and bayonets in the enactment of masculinity}

Before examining the drawings themselves, there is an important distinction to be made between soldier and home front culture during the First World War. During the conflict, soldiers' perceptions of masculinity and manliness evolved in a different social and cultural context to those of men on the home front. So, too, did the role and symbolism associated with the rifle and bayonet. For example, violent propaganda and recruitment campaigns had a more direct impact on the relationship between weapons and manliness for men at home in Australia than they did for those on active service. Art and posters (especially enlistment posters in 1914-15) celebrated the shooting of the rifle and the fixed bayonet. ${ }^{18}$ Patriotic songs declared that 'to be a man' was to 'take your gun', 'steel your arm' and 'stand ready at the guns'. ${ }^{19}$ Accompanying calls to 'cut down your cricket and your football/ [and] Go and learn to use a gun', the title pages of music scores often featured photographs or drawings of soldiers with fixed bayonets. ${ }^{20}$ On the home front, rifles and bayonets were clearly associated with militaristic masculinity, and for a number of new recruits they were likely considered evidence of one's manliness.

The valorisation of the rifle and bayonet as symbols of soldiering on the home front, the persisting concerns over athleticism and the glorification of the soldier certainly influenced the way men enacted their own masculinity with their weapons at war. However, as John McQuilton and Bill Gammage have pointed out, many men enlisted in the AIF because they were attracted by the prospect of employment, rather than more noble or idealistic causes. ${ }^{21}$ The decline in the mining business, the drought of 1914, and the industrialisation of farming in the years before the outbreak of war were influential in shaping the profile of the AIF. Many labourers and tradesmen, who made up just over 50 per cent of occupations for enlisting soldiers, saw military service as an opportunity for work. Thus, weapons_especially the rifle-were more likely to figure as a part of a soldier's daily toolkit and serve as evidence of their work ethic rather than physical supremacy while abroad. ${ }^{22}$

18 Examples of Australian enlistment posters include Quick! Give us a hand old sport, c. 1914-1918, AWM, ARTV08942; Don't stand looking at this: Go and help!, c. 1915, NLA, ID2629777; Norman Lindsay and W. A. Gullick Government Printers, The trumpet calls, c. 1918, AWM, ARTV00039; Harry J. Weston, NSW Government and W. A. Gullick Government Printer, We took the Hill, come and help us keep it!, 1915, AWM, ARTV00140; Syno, Australia has promised Britain 50,000 more men, 1915, AWM, ARTV00021.

19 Arthur Morley, 'Be a man, enlist to-day', 1914-1916, NLA, 133778; George Woolmer, 'Soldiers of Australia', 1914?, NLA, 2862377; Herbert Hadwen-Chandler, 'To arms, Australia!', 191?, SLWA, KDW/KM.

20 Alfred Mansfield, 'Wake up! Australia', 1914, NLA, 2161143; Evelyn Dell and Frederick Gladdish, 'He was only a private-that's all', 1915, NLA, 3310281; Hadwen-Chandler, 'To arms, Australia!'; Alan M. Rattray, 'Don't forget Australia: You've got your mother's eyes on you', 1916, NLA, 214568; Reginald de Talworth, 'Australia's brave soldiers: You're the one', 1916, NLA, 703321; Woolmer, 'Soldiers of Australia'.

21 John McQuilton, Journal of the Australian War Memorial, no. 33 (2000), www.awm.gov.au/journal/j33/mcquilton/; Bill Gammage, The Broken Years: Australian Soldiers in the Great War (Ringwood, VIC: Penguin Books, 1982), 10.

22 Ernest Scott, 'Volume XI-Australia During the War', in Official History of Australia in the War of 1914-1918 (Canberra: Australian War Memorial, 1941), 874. 
Therefore, although the bayonet and rifle were often closely associated with militaristic masculinity on the home front, for a number of soldiers on active service, these two weapons became entangled with 'working-man' as well as militaristic masculinity. While the relationship between these weapons cannot be entirely separated, their aesthetic qualities were distinctive. In the drawings of the men of the AIF between 1914 and 1918, the bayonet took on an aggressive quality that aligned with militaristic masculinity, while the rifle adopted a passive depiction that was clearly associated with 'working-man' masculinity.

\section{The bayonet as an enactment of militaristic masculinity}

Since classical times, bladed weapons designed for cutting and stabbing have embodied militaristic ideals. Japanese samurai swords, Highlander claymores, the spears of Greek hoplites and the bayonets and swords of Napoleonic soldiers are all examples of military groups that held explicit links between militaristic masculinity and weaponry. ${ }^{23}$ As the nearest modern alternative, the bayonet played an important role in affirming soldiers' aggression and proficiency of arms during the First World War. For the men of the AIF, it came to symbolise martial superiority, especially from the viewpoint of belligerent nations who, as John Norris and Rob Engen have observed, considered the bayonet the most confronting and feared weapon in a soldier's arsenal. ${ }^{24}$ Its significance has been continually reiterated over the last 200 years by French, British and German armies alike. ${ }^{25}$ Aaron Pegram has argued that, for the AIF soldier, the bayonet was crucial in 'imbuing troops with the morale and confidence to overwhelm their enemy at close quarters and gain the ground from him. ${ }^{26}$ Others have considered the bayonet 'the highest achievement of warrior culture' that played a powerful psychological role in evoking aggressive behavioural responses in men. ${ }^{27}$

In the diaries and letters of the men of the AIF, bayonets were frequently used as evidence of soldiers' willingness to fight and their physical superiority over enemy forces. Claims that the enemy 'would not face our steel' or fled upon seeing the glint of the bayonet were often used as proof of men's aggression and skill in battle. ${ }^{28}$

\footnotetext{
23 Herbert Sussman, Masculine Identities: The History and Meanings of Manliness (California: ABC-CLIO, 2012), 19, 21-24, 83.

24 Rob Engen, 'Steel Against Fire: The Bayonet in the First World War', Journal of Military and Strategic Studies 8, no. 3 (2006), 21; Dave Grossman, On Killing: The Psychological Cost of Learning to Kill in War and Society, 1st edition (Boston: Little Brown, 1995), 121-122.

25 For references to training manuals see Capt Michael M. O'Leary, 'A la Bayonet, or, "Hot Blood and Cold Steel"', Journal of Non-lethal Combatives (1999); K. S. F. Edward Costello, The Adventure of a Soldier; of, Memoirs of Edward Costello, K.S.F. (London: Henry Colburn, 1841), 203; 'SS119: Preliminary Notes on the Tactical Lessons of Recent Operations' (1916), 2, cited in Martin Samuels, Command or Control? Command, Training and Tactics in the British and German Armies, 1888-1918 (London: Frank Cass Publishers, 2003).

26 Aaron Pegram, 'The Spirit of the Bayonet', Wartime (2009), 53.

27 Joanna Bourke, An Intimate History of Killing: Face-to-face Killing in Twentieth-Century Warfare (London: Granta Books, 1999), 41; John Stone, 'The Point of the Bayonet', Technology and Culture 53, no. 4 (2012), 899-901; O'Leary, 'A la Bayonet, or, "Hot Blood and Cold Steel"'.

28 Pegram, 'The Spirit of the Bayonet', 53.
} 
In reality, the bayonet barely performed anything more than an auxiliary function in combat. ${ }^{29}$ Despite its continual use in training exercises during the war, it was largely an impractical weapon, usually only secured to the rifle on the command of officers immediately before men charged 'over the top', or during planned assaults such as raids. ${ }^{30}$ Soldiers were not typically shouldering fixed bayonets, and rarely found themselves in a situation to use one. ${ }^{31}$ Alongside casting doubt over the reliability of many of the accounts about the bayonet in soldiers' warwritings, the commonality of violent literary accounts with the weapon reiterates its psychological power: it relieved concerns over martial superiority and men's capacity for aggression. In the same way the men of the AIF used the bayonet to affirm their capacity for violence in written accounts, their drawings often pictured the weapon with a distinctively offensive character.

In this article, 91 drawings include the rifle and only 55 the bayonet. The bayonet is fixed-secured to the end of the rifle-in 40 of the 55 drawings. In other words, 26 artists, none of whom served in the same unit, are largely drawing themselves ready for combat. This statistic is made even more striking considering that 96 per cent of rifles are not positioned in an aggressive position (Fig. 11). Essentially, most of the artists in this study have disregarded accuracy and realism in order to depict the bayonet armed where it would otherwise not be appropriate. For example, in drawings by Garnet Williamson, Fred Knowles, John Dunbar and Marshall the bayonet is fixed while soldiers have a smoke (Figs 1, 2 and 9). ${ }^{32}$ A page in Roy Jacobs' sketchbook has three separate drawings of 'The Digger' with a fixed bayonet, including one where he is 'going in' to battle with a fixed bayonet slung over his shoulder and another where he his 'coming out' wounded (Fig. 5). ${ }^{33}$ Similarly, three of Marshall's cartoons in 1917 and two drawings by Geoffrey Townshend picture soldiers walking around with fixed bayonets slung over their shoulder (Figs 6 and 7). ${ }^{34}$ Notably, there is no known evidence, visual or otherwise, that supports the notion that soldiers were walking around with fixed bayonets slung over their shoulders, which would have been dangerous, impractical and uncomfortable. Other drawings

\footnotetext{
29 Stone, 'The Point of the Bayonet', 888.

30 Hodges, 'They Don't Like It up 'Em!: Bayonet Fetishization in the British Army during the First World War', Journal of War \& Culture 1, no. 2 (2008), 123; Pegram, 'The Spirit of the Bayonet', 52; Stone, 'The Point of the Bayonet', 885; Everett Dauge and Spencer C. Tucker, 'Bayonets', in World War I: The Definitive Encyclopedia and Document Collection, ed. Spencer C. Tucker (Santa Barbara, California: ABC-CLIO, 2014), 224-225.

31 The proportion of casualties attributed to the bayonet during the First World War was extremely small, some scholars estimating less than 1 per cent. See Stone, 'The Point of the Bayonet', 888.

32 Garnet Angus Williamson, 'Aussie leaning on his rifle', 1918, AWM, ART03573; Fred Knowles, With the Dinkums, vol. I (Sydney: NSW Bookstall Co. Ltd, 1918), 18, 22; John Dunbar, 'Dressed to Kill, Two Styles', 1918, AWM, ART94463.017; Marshall, '35. Recollection during a lull in the fight, Bullecourt, 19/5/17', in Sketches of the Somme, 1917.

33 Roy C. Jacobs 'The Digger', in Sketches of warfare in World War I, 1915, SLNSW, PXE 714.

34 Marshall, '19. "Officer looking for his unit' - 'One of those "adorable? ANZACS”...' and '13. "The first night in ...”. See also Marshall, 'no. 17', in 2453 Pte. J. Marshall, 53rd Battalion H. Q., A.I.F., France, 1918, PXA 381 (v. 4); Geoffrey K. Townshend, 'On Guard', in Geoffrey Keith Townshend War Sketches, no. 64, 1916-1919, SLNSW, PXA 383; Townshend, 'Untitled', in Geoffrey Keith Townshend War Sketches, no. 206.
} 
have soldiers standing guard, attending meetings (often with officers) or gazing out into the distance with a fixed bayonet at their side (Figs 3, 4, 5 and 8). ${ }^{35}$ On all occasions, the armed position of the bayonet is unrealistic.

The lack of realism is revealing: soldier-artists are emphasising the relationship between the bayonet and the manly virtues associated with militaristic masculinity. This is seen clearly in a drawing by Knowles in a published collection that pictures a 'shirker' being reprimanded by an officer. ${ }^{36}$ The short and puny-looking man is drawn without his weapon, while his fellow comrade-a fit and muscular manstands with a fixed bayonet at his side. In Knowles' drawing, the fixed bayonet is used as a symbol of a soldier's physical superiority, and perhaps even his bravery and morality. Another artist uses text to link the bayonet with expressions of aggression. According to Dunbar, when a soldier is 'Dressed to Kill' his bayonet is fixed to his rifle (Fig. 9). ${ }^{37}$ Ironically, using the bayonet in combat was highly uncommon and stabbing someone a rarity. ${ }^{38}$ The preference then, to depict the bayonet fixed to the rifle, is not representative of how soldiers commonly engaged with the weapon but rather externalises a perceived sense of masculine aggression and physical supremacy.

A second notable feature in soldiers' drawings that supports the argument that artists were exaggerating, or at least misrepresenting, the bayonet is its susceptibility to incorrect depiction. Though misrepresentation is hardly a dominant trend, there are instances where the bayonet is drawn up to double or half its length or thickness. For example, Leslie Hore's 'Stand to arms ...' has the bayonet far longer than its real-life equivalent, and in 'The first night in ...' Marshall drew the bayonet as if it were some kind of medieval great sword (Figs 7 and 8). ${ }^{39}$ The inaccuracies in the proportions for the bayonet are worth noting for two reasons. First, it is in stark contrast to the accuracy granted to the rifle. With the exception of Marshall's drawing, all other exaggerations or reductions in scale for the bayonet are not replicated in the rifle. ${ }^{40}$ For example, in Dunbar's 'Dressed to Kill, Two Styles' and Marshall's 'Recollection ...', the exaggerated thickness of the bayonet is not consistent with the rifle (Figs 2 and 9). ${ }^{41}$ Second, other drawings completed by these soldier-artists depict the bayonet

35 Niel A. Gren, 'Untitled', in Niel A. Gren's World War I Sketches, no. 3, SLNSW, PXD 508/4-7; Frank Dunne, 'Untitled', 1915-1916?, AWM, ART12455; Jacobs, 'The Digger'; Leslie Hore, '12. Stand to Arms ...' in Sketches at Gallipoli, 1915, 1915, SLNSW, PXE 702. See also Marshall, '27. The Observer ...', in Sketches of the Somme, 1917; Townshend, 'On guard outside billet', Geoffrey Keith Townshend war sketches, no. 158; William K. Eltham, 'North flank, Sulva from Anzac', 1915, AWM, ART00043.

36 Knowles, With the Dinkums, 18.

37 Dunbar, 'Dressed to Kill, Two Styles'.

38 Stone, 'The Point of the Bayonet', 888.

39 Hore, '12. Stand to Arms ...'; Marshall, '13. "The first night in ...”. Other examples include Jacobs, '4. Gallipoli, 25 April 1915-Abdul-Fatima-Sister Riley’ in Roy C. Jacobs A.I.F. [Sketchbook], 1915, SLNSW, PXE 704; Jacobs, '4. The Test of Courage', in Sketches of Warfare in World War I; Benjamin H. E. Price, 'Our listening post was withdrawn', 1918, AWM, ART94802; Frank Dunne, “'Pull yourself together, man”', 1915-18, AWM, ART12448; Dunne, 'Untitled'.

40 Marshall, '13. "The first night in ..."'

41 Marshall, '35. Recollection during a lull in the fight, Bullecourt, 19/5/17'; Dunbar, 'Dressed to Kill, Two Styles'. 
in proportion, indicating that the exaggeration or reduction in size is not indicative of unfamiliarity or a lack of artistic skill. Although the inconsistency in proportions does not directly support the argument that bayonets were being used to enact militaristic masculinity, it hints at the way artists were embellishing its depiction. Soldiers were drawing the bayonet differently to its typical use in order to endow it with an aggressive quality that it otherwise would not have had.

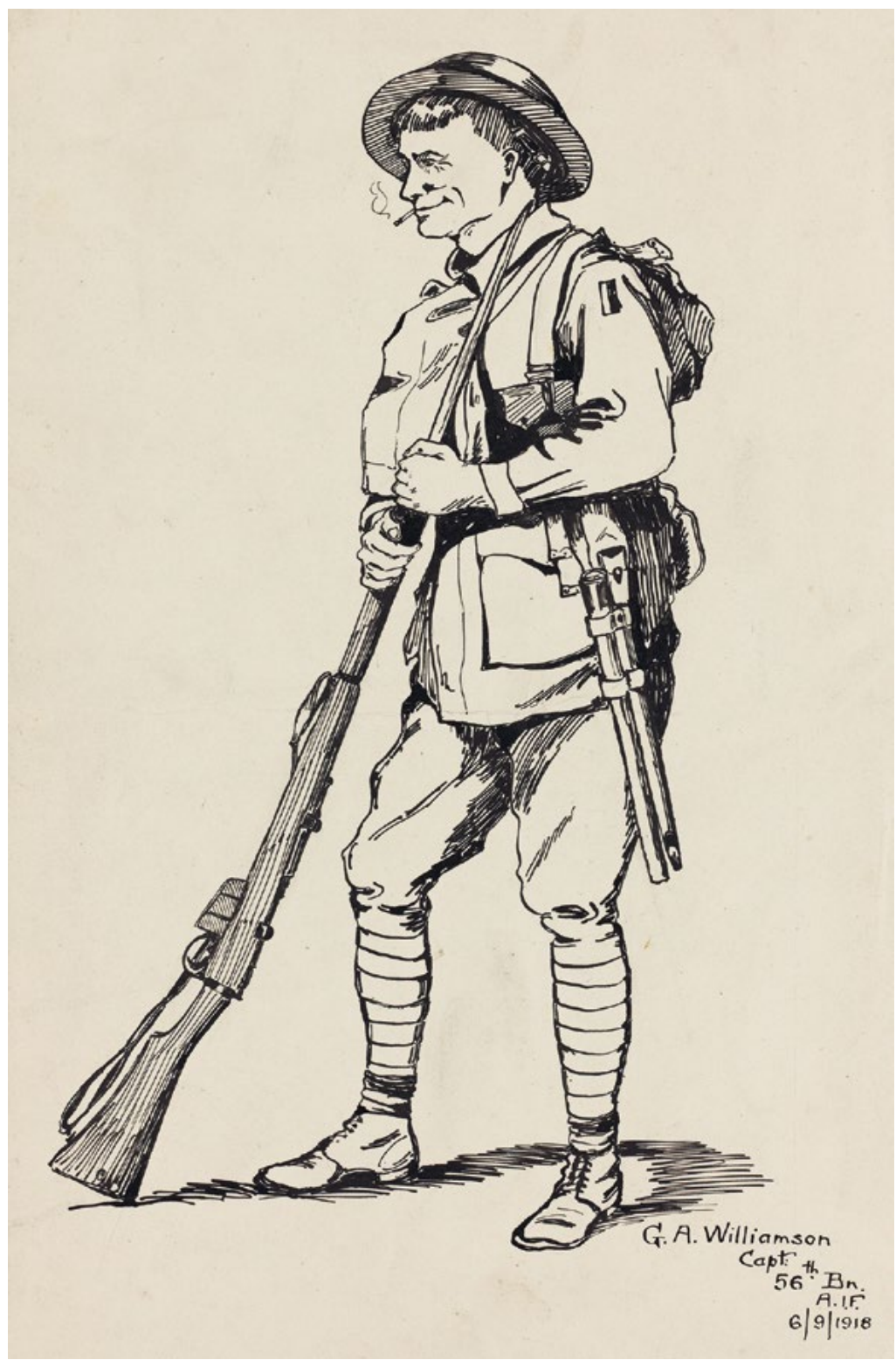

Figure 1: 'Aussies leaning on his rifle' by Garnet A. Williamson, 1914-18. Source: Australian War Memorial (AWM, ART03573). 


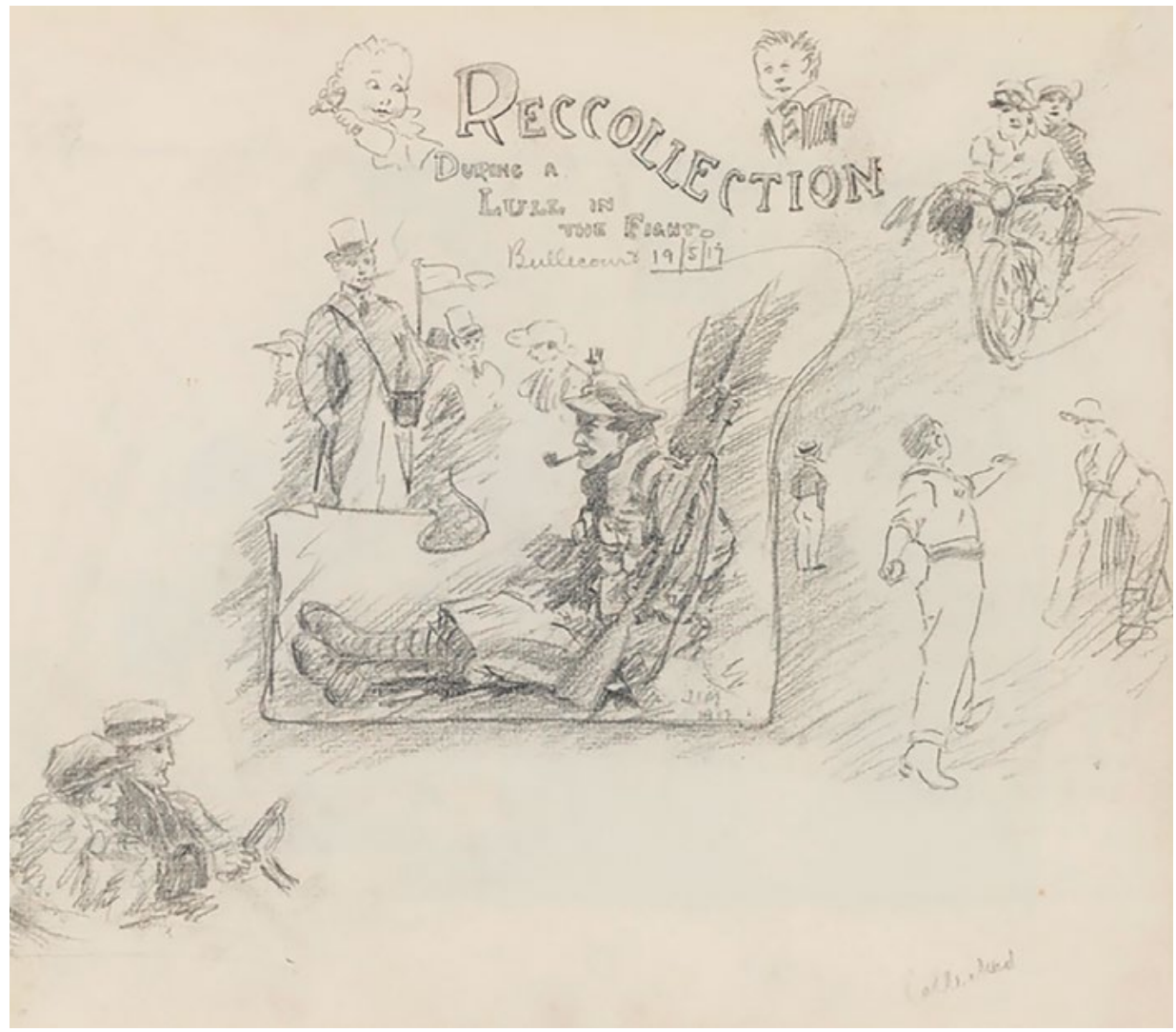

Figure 2: 'Recollection during a lull in the fight, Bullecourt, 19/5/17' by James J. Marshall from Sketches of the Somme, 1917, 1917. Source: State Library of New South Wales (SLNSW, PXA 381 (v. 2)). 


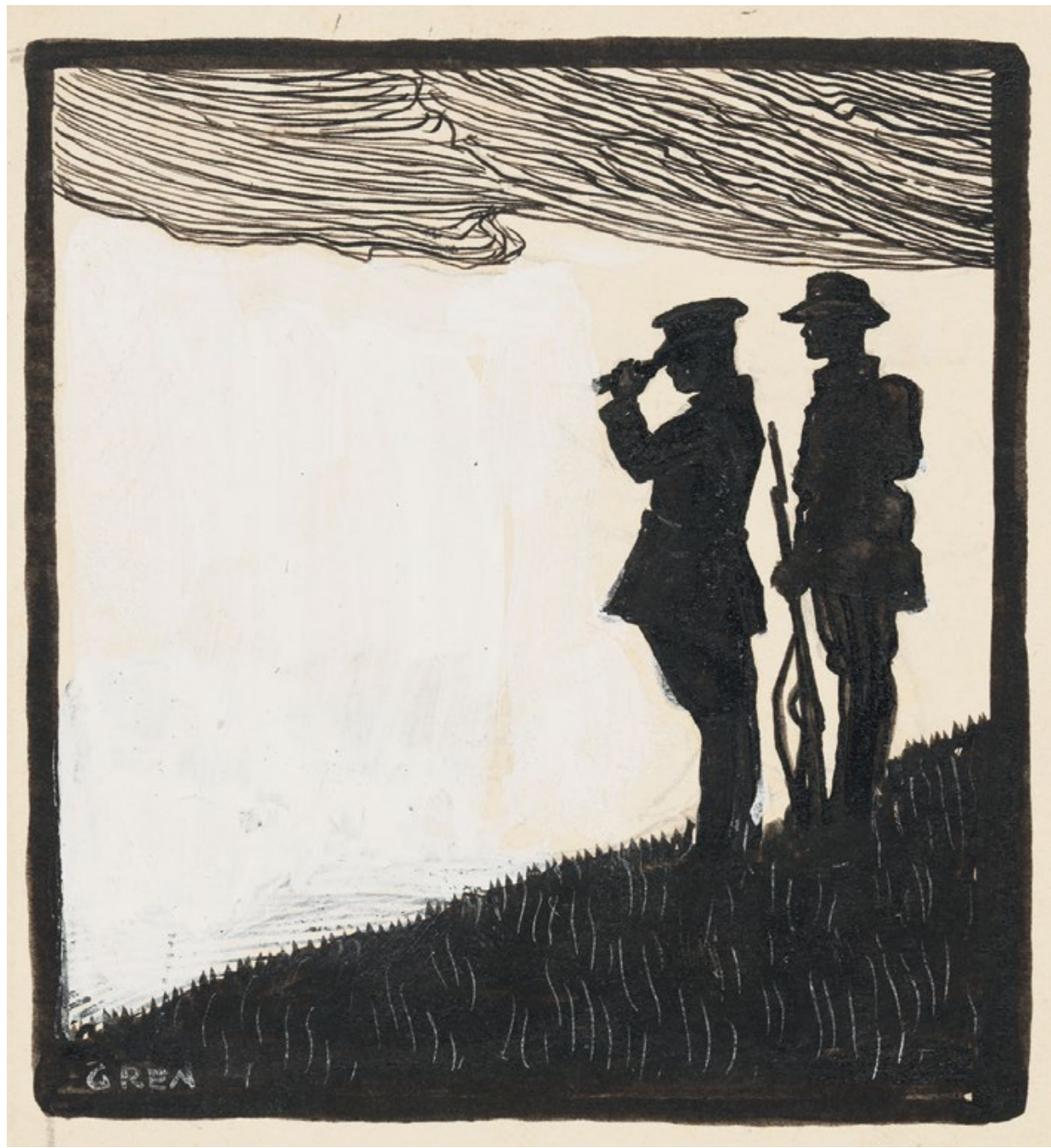

Figure 3: 'Untitled' by Niel A. Gren from Niel A. Gren World War I Sketches Collected by Miss A. A. N. Small, 1916.

Source: State Library of New South Wales (SLNSW, PXD 508/4-7). 


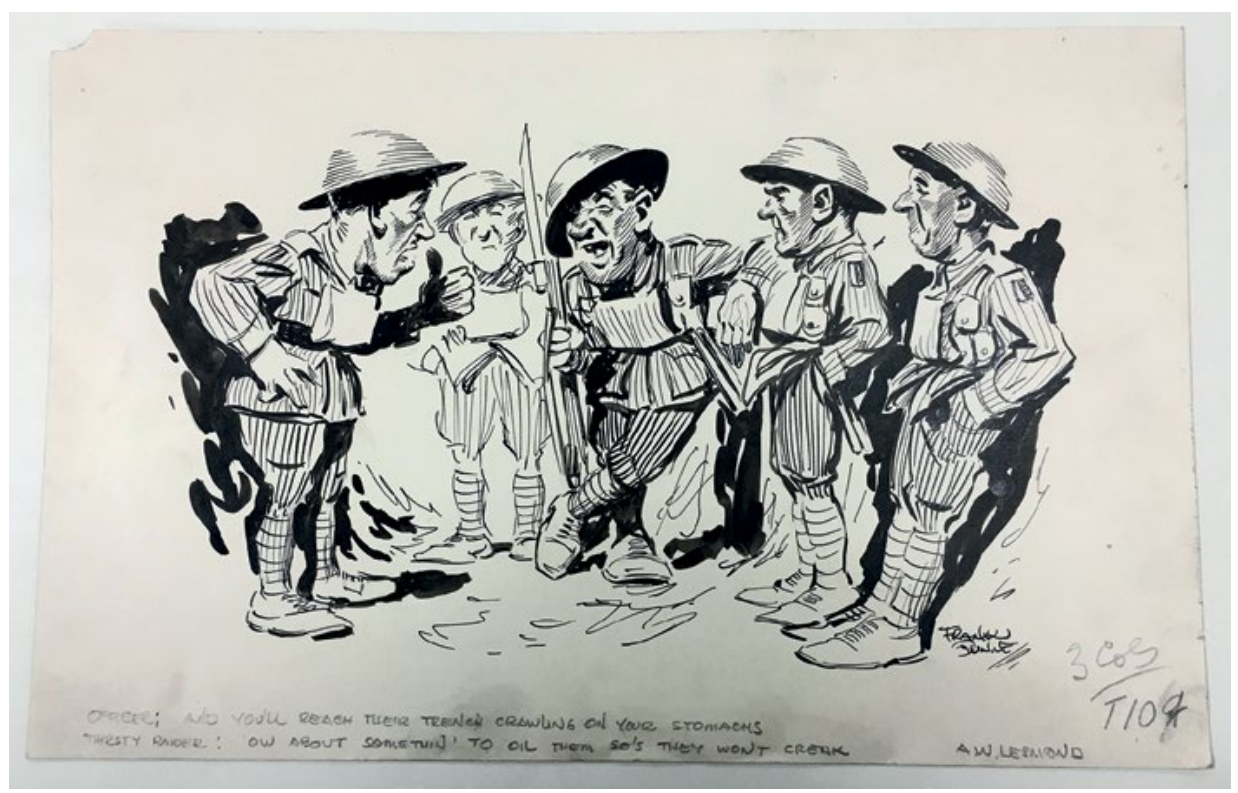

Figure 4: 'Untitled' by Frank Dunne, 1915-16? Source: Australian War Memorial (AWM, ART12455).

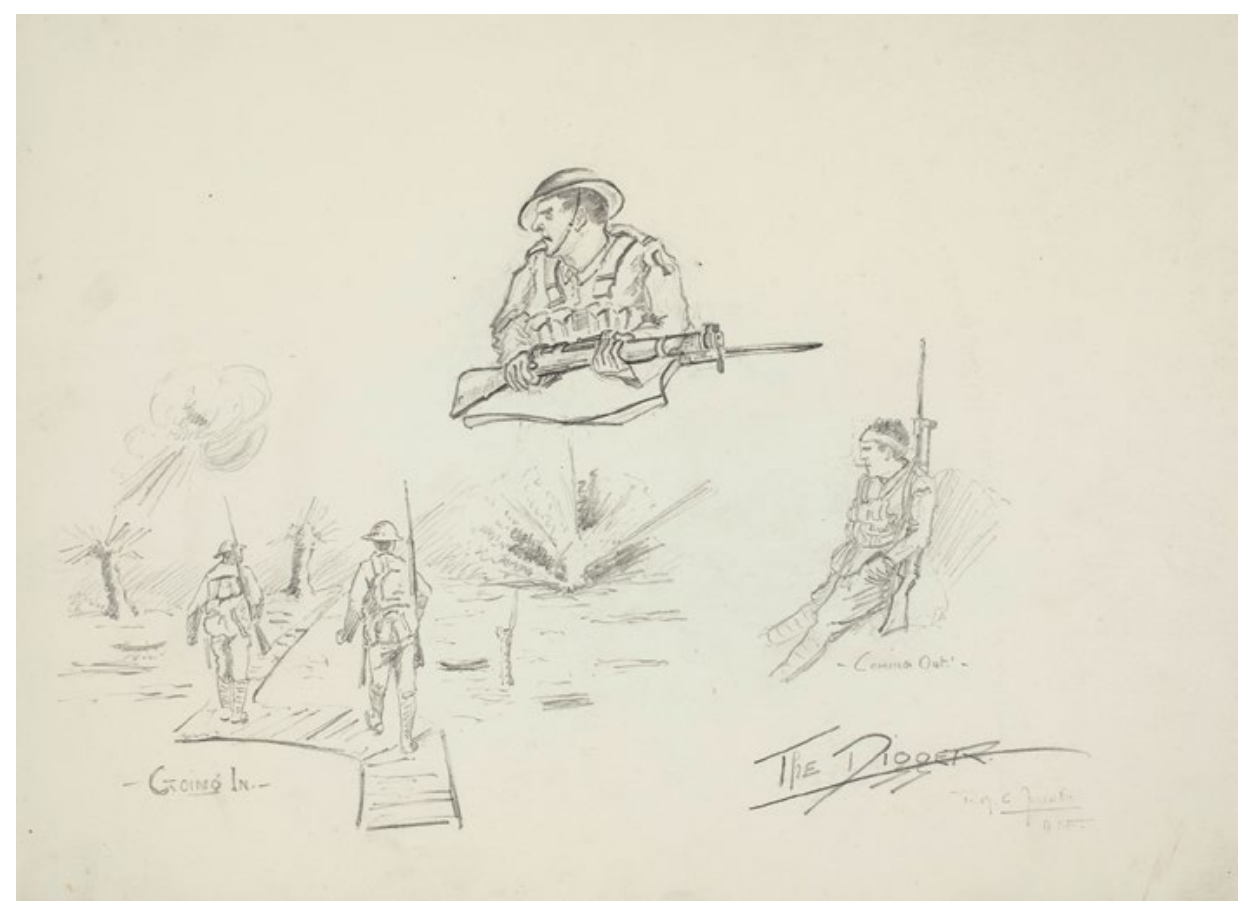

Figure 5: 'The Digger' from Roy C. Jacob's Sketches of Warfare in World War I, 1917.

Source: State Library of New South Wales (SLNSW, PXE 714). 


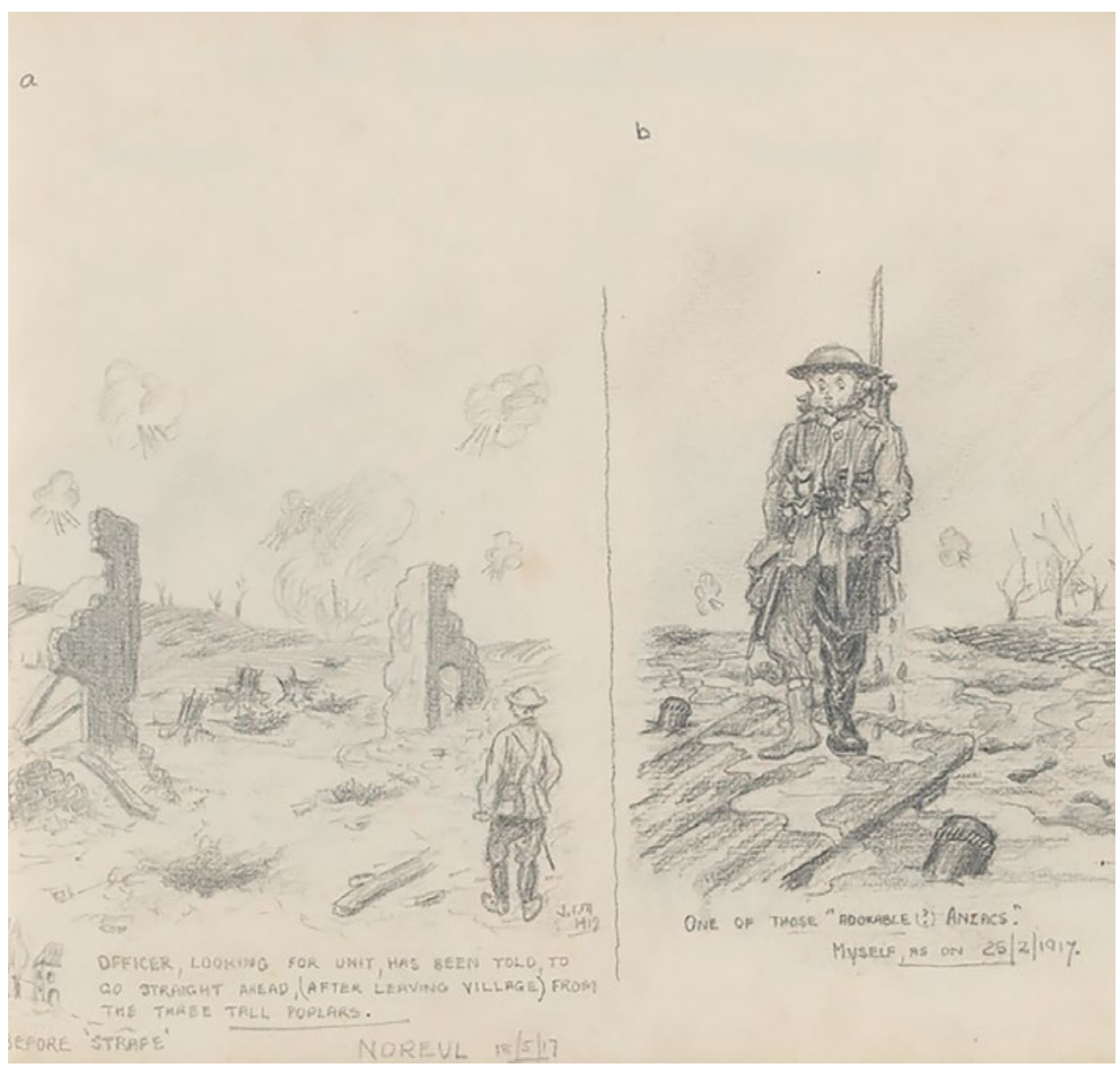

Figure 6: "19. "Officer looking for his unit"- "One of those "adorable? ANZACS'..."' by James J. Marshall from Sketches of the Somme, 1917, 1917.

Source: State Library of New South Wales (SLNSW, PXA 381 (v. 2)). 


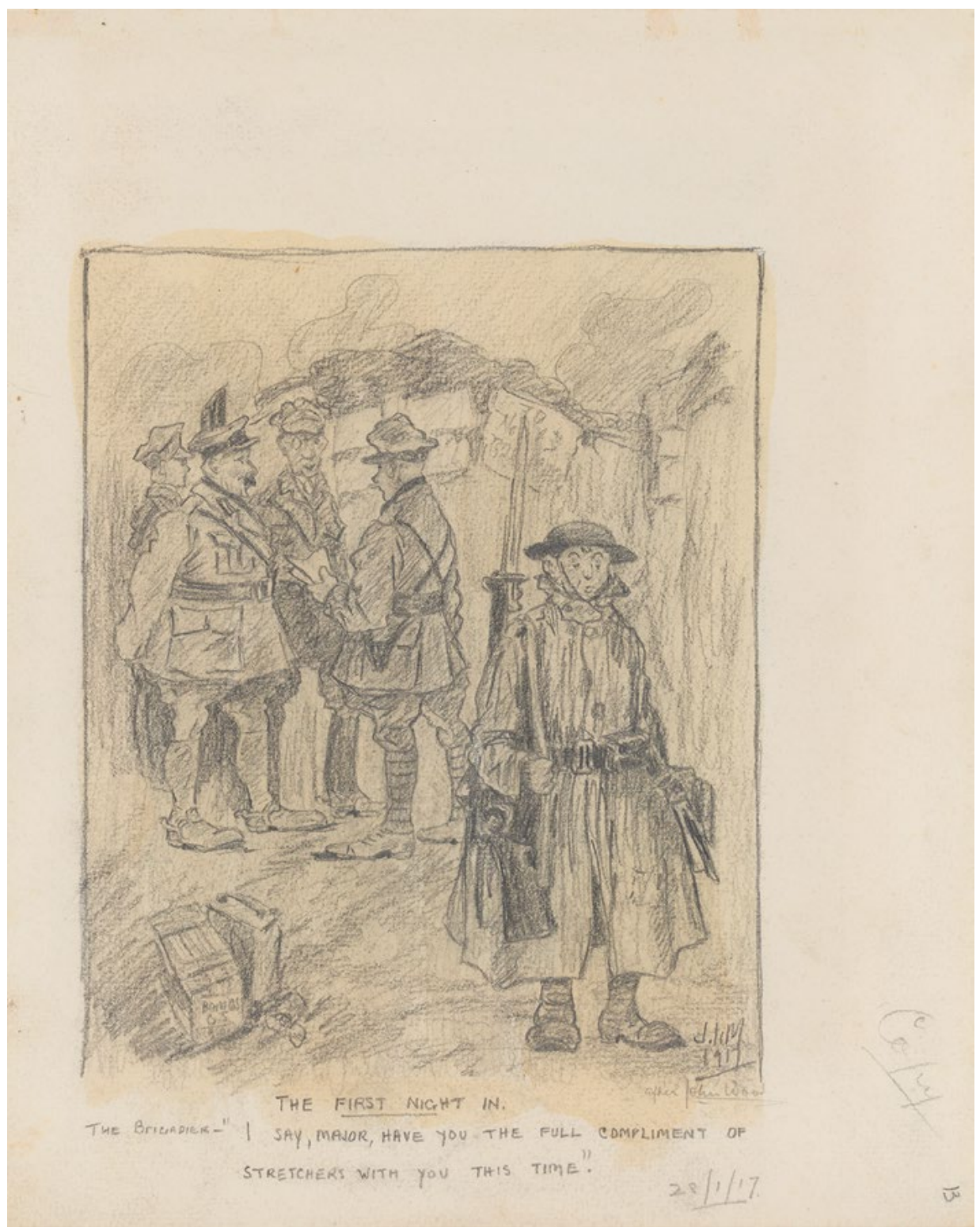

Figure 7: '13. "The first night in ..."' by James J. Marshall from Sketches of the Somme, 1917, 1917.

Source: State Library of New South Wales (SLNSW, PXA 381 (v. 2)). 


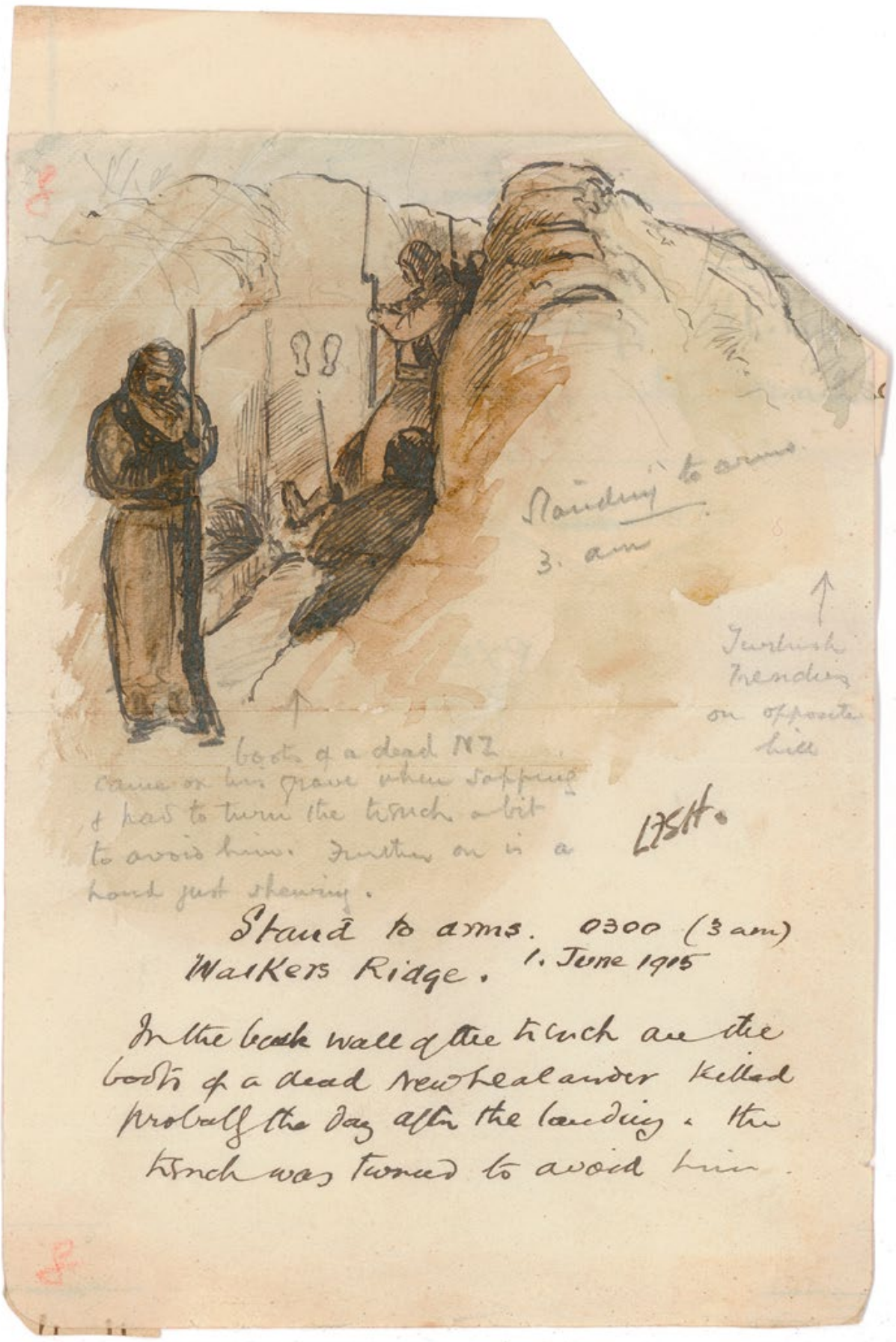

Figure 8: 'Stand to arms ...' by Leslie Hore in Sketches at Gallipoli, 1915. Source: State Library of New South Wales (SLNSW, PXE 702, 1915). 

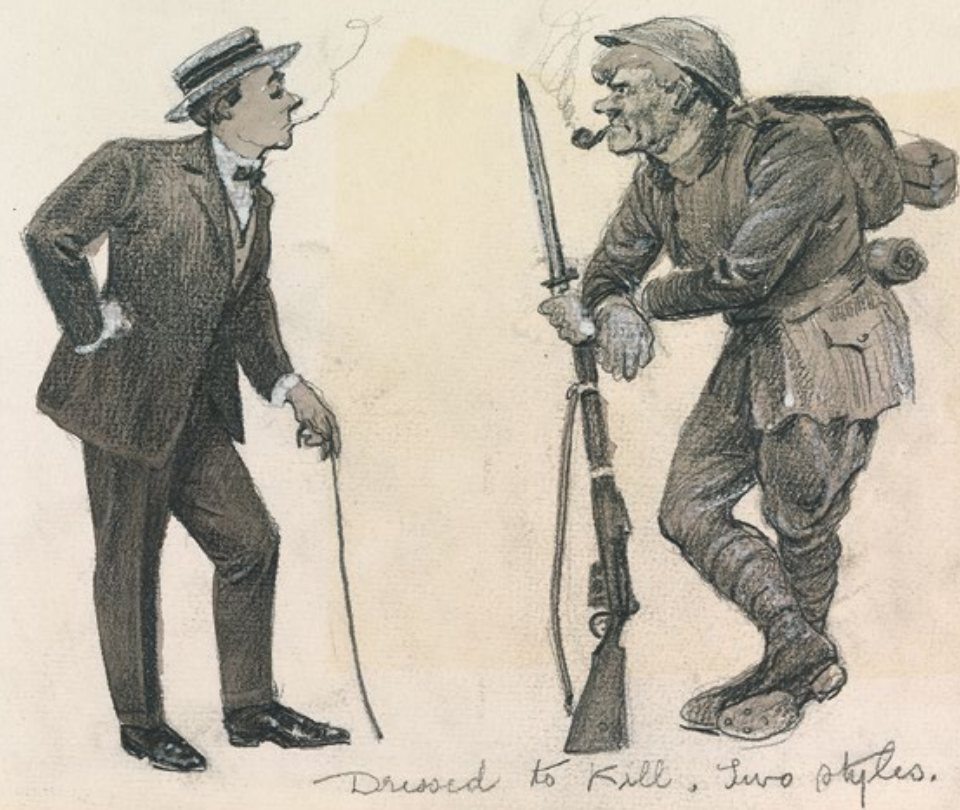

Figure 9: 'Dressed to Kill, Two Styles' by John Dunbar, 1918. Source: Australian War Memorial (AWM, ART94463.017, 1918).

\section{The rifle as an enactment of 'working-man' masculinity}

In his study 'Disarming Masculinity', the European researcher Henry Myrttinen argues that 'weapons are part of one notion of masculinity, a militarized view that equates "manliness" with the sanctioned use of aggression, force and violence'. 'Their public display seek to underline the "manly" prowess of the bearer. ${ }^{\text {'42 }}$ Though Myrttinen acknowledges that the characteristics associated with militaristic masculinity vary between cultures, he contends that rifles, bayonets, projectile weapons and modern nuclear technology all perform similar 'violent' functions in visual culture. ${ }^{43}$ However, the notion that 'all' weapons performed the same symbolic function - to promote aggression and affirm martial prowess-is not substantiated in Australian soldiers' drawings during the First World War. In this medium, rifles often resist and undermine the aggressive qualities consistently endorsed by the bayonet, as soldiers drew rifles with a passive, utilitarian and anti-agentive quality, evoking images associated with the 'working man' rather than militaristic masculinity.

42 Henri Myrttinen, 'Disarming Masculinties', Women, Men, Peace and Security 4 (2003), 37-38. See also Henri Mryttinen, "Pack Your Heat and Work the Streets"-Weapons and the Active Construction of Violent Masculinities', Women and Language 27, no. 2 (2004), 26-29.

43 Scholars advancing Freudian theory on the symbolic phallic quality also bracket 'weapons' under one category, failing to differentiate the roles different weapons may play in enacting masculinities. See Joanna Bourke, An Intimate History of Killing, 20, 137-138, 302; Grossman, On Killing, 125, 134-136. 
In the decades approaching 1914, the masculine ideal of the working man venerated the manly virtues of hard work, manual labour and domesticity, valuing soldiering as a form of work rather than for its capacity to cultivate aggression or improve men's fitness. Male maturity was not achieved through martial supremacy or national self-sacrifice, but through sheer hard work. Due to the existing divisions in the historiography, there is a temptation for scholars to see the virtues of the working man as undermining those of the militaristic man. Certainly, men who are not enacting militaristic masculinity are enacting an alternative (or alternatives). Yet, as this article demonstrates, these two masculinities could exist concurrently, enacted simultaneously in the same drawing but represented in two different weapons. In the context of the broader collection of unarmed drawings, alongside an understanding of the nature of military service, the rifle can be seen as resisting, though nearly always coexisting, with the militaristic virtues enacted by the bayonet.

Of the drawings in this study, 96 per cent depict the rifle in a passive position (Fig. 10). This is in stark contrast to the aggressive depiction that characterises depictions of the bayonet. Of the 91 drawings in this study, there are only four occasions where the rifle is pictured as if it is being used for fighting: in three instances the rifle is shouldered and in the other it is held aggressively in two hands. In all of the images included in this study (Figs 1-9 and 11-20), with the exception of Jacobs' 'The Digger' (Fig. 5), the rifle is shouldered, at ease or on the ground-all distinctively passive positions. The notion that the rifle was a symbol of aggression or physical prowess for soldiers of the AIF is rarely consistent with its visual depiction.

\begin{tabular}{|l|c|c|}
\hline Position & Number of depictions & $\begin{array}{c}\text { Percentage of total } \\
\text { (rounded to whole) }\end{array}$ \\
\hline Shouldered & 3 & $3 \%$ \\
\hline Slung over the shoulder & 22 & $22 \%$ \\
\hline Carried single-handed & 27 & $27 \%$ \\
\hline Carried two-handed & $7^{*}$ & $7 \%$ \\
\hline On the ground & 22 & $22 \%$ \\
\hline $\begin{array}{l}\text { At ease (butt of the rifle perpendicular } \\
\text { to the ground) }\end{array}$ & 18 & $18 \%$ \\
\hline Total & $\mathbf{9 9 * *}$ & $\mathbf{1 0 0 \%}$ \\
\hline
\end{tabular}

Figure 10: Nature and frequency of rifle positions in the 91 examined soldiers' drawings 1914-18.

* In one drawing the weapon is held aggressively.

** The total is larger than the number of drawings as eight drawings depicted the rifle in more than one position.

Source: Author. 
In part, the passive depiction of the rifle is representative of the nature of military service. Less than half of a First World War soldier's military service was spent in the front lines, of which only a fraction was in combat. ${ }^{44}$ Manual labour was the primary occupation for most men, and, except in profile or character drawings, soldiers predominately drew the hardships of soldiering: billets, patrols, marches, fatigues, sapping and travelling. For example, Robert Harris, who saw action in New Guinea, Gallipoli and France, often drew marches or landscapes in his diary (Fig. 15) ${ }^{45}$ During his time in Gallipoli and vicious combat in the Somme in July 1916, Harris' diary is noticeably absent of combat drawings. ${ }^{46}$ Similarly, rather than a battle scene of the fierce fighting during the Somme Campaign in February 1917, Marshall included a sketch of himself walking through the muddy landscape (Fig. 6). ${ }^{47}$ Though Marshall's drawing includes the fixed bayonet, the rifle remains in a passive position. A number of other drawings feature soldiers marching, standing on guard, sitting in dugouts or trenches, engaging in physical labour (even in the midst of enemy fire) or performing the more mundane aspects of 'the job', such as cooking. ${ }^{48}$ In these drawings, rifles tend to accompany every day manual labour, enacting the manly virtues of hard work and resilience.

The argument that soldiers primarily used rifles as symbols of work is endorsed by the broader visual trends of the drawings in this study. Many of the 24 artists who contributed the drawings under analysis produced dozens, or in some cases hundreds, of others without the rifle and bayonet. These drawings are predominately a mixture of landscape, portraits and depictions of men engaging in labouring tasks. For example, the 10 sketches included in this study from Townshend's collection were drawn from a larger collection of 210 drawings. Alongside landscape and touristic pieces, Townshend includes a number of drawings where men are working communications, pulling carts or animals, carrying buckets, billeting, serving artillery, building dugouts and engaging in pastoral activities (Figs 16, 18 and 19). ${ }^{49}$ Similarly, Hore sketched a number of drawings of unarmed soldiers working at Anzac Beach, Mule Gully, Gurkha Camp and North Beach, while Dudley Walford

44 Wise, Anzac Labour, 54-55.

45 Robert Harris, 'Our Divisional Rest', Robert Harris Diary, 30 March 1916-28 March 1917, SLNSW, MLMSS 2773/3, 24.

46 Robert Harris, Robert Harris Diaries, 17 August 1914-27 December 1918, SLNSW, MLMSS 2773.

47 Marshall, '19. "Officer looking for his unit ..."'.

48 For example, Cyril Leyshon White, 'Anzac Types', in The Anzac Book, 3rd edition (Sydney: University of New South Wales Press, 2010); Harris, 'no. 7' and 'no. 24' in Robert Harris Diary, 30 March 1916-28 March 1917; John Dunbar, 'Mud!', 1914-18, AWM, ART19520.003; Townshend, 'no. 12', 'no. 95' and 'no. 158', in Geoffrey Keith Townshend War Sketches; Marshall, '19. "Officer looking for his unit ...”'; Marshall, '35. Recollection during a lull in the fight, Bullecourt, 19/5/17'; Reginald Harwood Addison, 'not titled [Two soldiers sitting in a covered trench, near Hazebrouck]', 1918, AWM, ART92338.015; Gren, 'no. 3'; Hore, '12. Stand to Arms ...'; Joseph Barton Meldrum, 'not titled [Track and dump looking towards the front line]', 1917, AWM, ART03192.009.

49 Townshend, 'Say Bill ...', 'X'mas Dinner ...' and 'Carry my 18 pdn shells ...', in Geoffrey Keith Townshend War Sketches. 
produced ink drawings in his diary of soldiers engaged in mining and transporting. ${ }^{50}$ Furthermore, the Kia Ora Coo-ee and The Anzac Book are filled with drawings of soldiers labouring. Many other artists that were not examined in this study, as they did not include drawings of the rifle and bayonet, also depict soldiers undertaking manual labour or pastoral work. Essentially, in the context of the broader collection of soldiers' drawings, the passive depiction of the rifle aligns with broader visual trends that picture soldiers 'working' rather than 'fighting'.

The commitment to the passive depiction of rifles is remarkable. Even the few drawings that picture soldiers in battle feature the rifle in inoffensive positions. In Jacobs' 'Beaumont Hamil, 3 April 1917', all armed soldiers aside from one man in the mid-ground are drawn charging with their rifles vertically oriented (Fig. 17)..$^{51}$ The passive positioning of the weapon undermines the aggressive quality of the fixed bayonet. Interestingly, the passivity of the rifle in combat drawings and the complete absence of combat drawings in other collections, including those by Marshall, Hore, Gould and Townshend, cannot be explained by a lack of combat experience. Most of the key contributors in this study were heavily involved in frontline combat before they completed their drawings. For example, Marshall of the 53rd Battalion spent the winter of 1916-17 in the trenches of the Somme and participated in the advance to the Hindenburg Line, fighting in Ypres in 1917 and the defence of Villers-Bretonneux on 24-25 April 1918. ${ }^{52}$ Townshend served three years in France with the 2nd Field Artillery Brigade, Hore fought in the Battle of the Nek in Gallipoli and at Pozières in France where he was awarded the Military Cross for conspicuous gallantry, and Gould served in Gallipoli with the 6th Battalion until the evacuation, later being mentioned in dispatches twice while serving on the Western Front. ${ }^{53}$ Yet, while there is no doubt that these men were familiar with using their rifles aggressively, they chose to draw them passively, resisting the virtues of militaristic masculinity.

Unlike the bayonet, the rifle was typically drawn with mechanical precision and in correct proportion to the human figure, rarely oversized or undersized. The rifle, which was either the Short Magazine Lee Enfield (SMLE) No 1 Mk III or Mk III*, was $113 \mathrm{~cm}$ tall..$^{54}$ It was rare for the rifle to sit below the soldiers' waist or above

50 Hore, Sketches at Gallipoli; Dudley, V. Walford, Dudley V. Walford diary, 23 Sep. 1914-13 Aug. 1916, 19141916, SLNSW, MLMSS 982/1.

51 Roy C. Jacobs, 'Beaumont Hamil, 3 April 1917', in Sketches of Warfare in World War I, 1915.

52 James J. Marshall (2455), Service Record, NAA, B2455; Frank M. Budden, The Mob: The Story of the 55/53rd Australian Infantry Battalion, A.I.F. (Sydney: F.M. Budden, 1973).

53 Geoffrey Keith Townshend (11415), Paper Files and Documents, NAA, B2455; Leslie Fraser Standish Hore, Paper Files and Documents, NAA, B2455; Charles Henry Gould (1552), Paper Files and Documents, NAA, B2455; Australian War Memorial, 'Biography of "Captain Charles Henry Gould”', www.awm.gov.au/people/P10678151/. 54 Ian Kuring, 'Small Arms in Australian Service', in The Oxford Companion to Australian Military History, ed. Peter Dennis et al. (Oxford: Oxford University Press, 2009); Edmund G. B. Reynolds, The Lee-Enfield Rifle (London: Herbert Jenkins, 1960), 212-213; Lithgow Small Arms Factory, 'Military Production at Lithgow SAF: .303 Short Magazine Lee Enfield (SMLE) Rifle No 1 MkIII and MkIII* Complete with Bayonet', www. lithgowsafmuseum.org.au/milproduction.html\#smle. 
his chest. ${ }^{55}$ Out of the 91 depictions of the rifle, only 10 are oversized and seven undersized. Drawings that have the rifle shorter than shoulder height such as Niel A. Gren's World War I Sketches are exceptional (Fig. 3). ${ }^{56}$ The few oversized rifles in this study are solely attributed to Marshall and Townshend. ${ }^{57}$ The consistent accuracy in proportions for the rifle is indicative of the depictive quality of these drawings. That is, soldiers are drawing the rifle in the way they commonly engaged with it, making it less prone to misrepresentation.

Lastly, there is an important relationship between the rifle, bayonet and heavy artillery that is worth noting. In the drawings that also include heavy enemy artillery, the passive depiction of the rifle and agentive positioning of the bayonet are both neutralised by shellfire, undermining the enactment of militaristic and 'working-man' masculinity by entirely denying soldiers' agency. Part of the power of the bayonet as a symbol of militaristic masculinity is the agency inherent in its use. Frequently recognised for its industrialised and mechanised style of combat, the First World War was a conflict that reduced men's capacity to control their environment and threatened their agency, often reducing men to passive victims. However, the bayonet harkened back to classical forms of warfare when soldiers had greater control of their circumstances and were able to decide their own fate. Conversely, the rifle represents continuity, reinforcing the importance of military service as a form of work. Yet, the symbolic functions of these two weapons are consistently threatened by heavy enemy artillery fire. For example, in drawings by Marshall, Jacobs, Price, Knowles, Harris and Frank Dunne, the utility of the rifle and bayonet is neutralised by the onslaught of enemy shellfire (Figs 11, 12 and 13). ${ }^{58}$ As shells loom overhead or strike the firing line, the rifle either lies on the ground out of reach or is positioned as 'useless', as in the case of Harris' drawing (Fig. 12). ${ }^{59}$ The trend continues without exception throughout all 13 drawings in this study that include both the rifle and enemy shellfire, suggesting that masculinity and manliness were threatened by the powerlessness that could often accompany modernised warfare. ${ }^{60}$ Notably, comedic depictions like page 10 from Harris' diary are not uncommon and almost serve to compensate for the lost agency inherent in many of these drawings - to laugh in the face of death as a final act of resistance (Fig. 13). ${ }^{61}$

55 The average height of recruits for the 1st Battalion and British soldiers was 5'6" $(167.64 \mathrm{~cm})$. See Dale James Blair, Dinkum Diggers: An Australian Battalion at War (Carlton,VIC: Melbourne University Press, 2001), $28-29$.

56 Gren, 'no. 3'.

57 Marshall, '19. “Officer looking for his unit ...”'; Townshend, 'Untitled', no. 206.

58 Marshall, '12. The "Minnies” comes!!!' and '33. The (K)night of the bath, Bullecourt, 21/5/17', in Sketches of the Somme, 1917; Harris, 'Untitled', in Robert Harris Diary, 24 July 1915-30 March 1916.

59 Harris, 'Untitled'.

60 Alexander Stone, 'Skit on a "better 'ole”', 1916, AWM, ART03471; Frank Dunne, 'You oughta try and 'ide that; yer might want it to sit on', 1914-18, AWM, ART12445; Frank Dunne, 'Missed again', 1914-18, AWM, ART12452; Benjamin Price, 'Our listening post was withdrawn', 1918, AWM, ART94802; Jacobs, 'Tank raiding an advanced post' and 'Polygon Wood, 1917', in Sketches of Warfare in World War I, 1918; Knowles, 'A little too late' and 'Quite Harmless', in With the Dinkums, 22, 35; Marshall, 'Greetings from above!', 'Where did that one go boys?' and 'Outpost, Zenith Trench', in Sketches of the Somme, 1917, no. 25, 27, 25.

61 Harris, 'Our Helmets', in Robert Harris Diary, 30 March 1916-28 March 1917, SLNSW, MLMSS 2773/3, 10. 


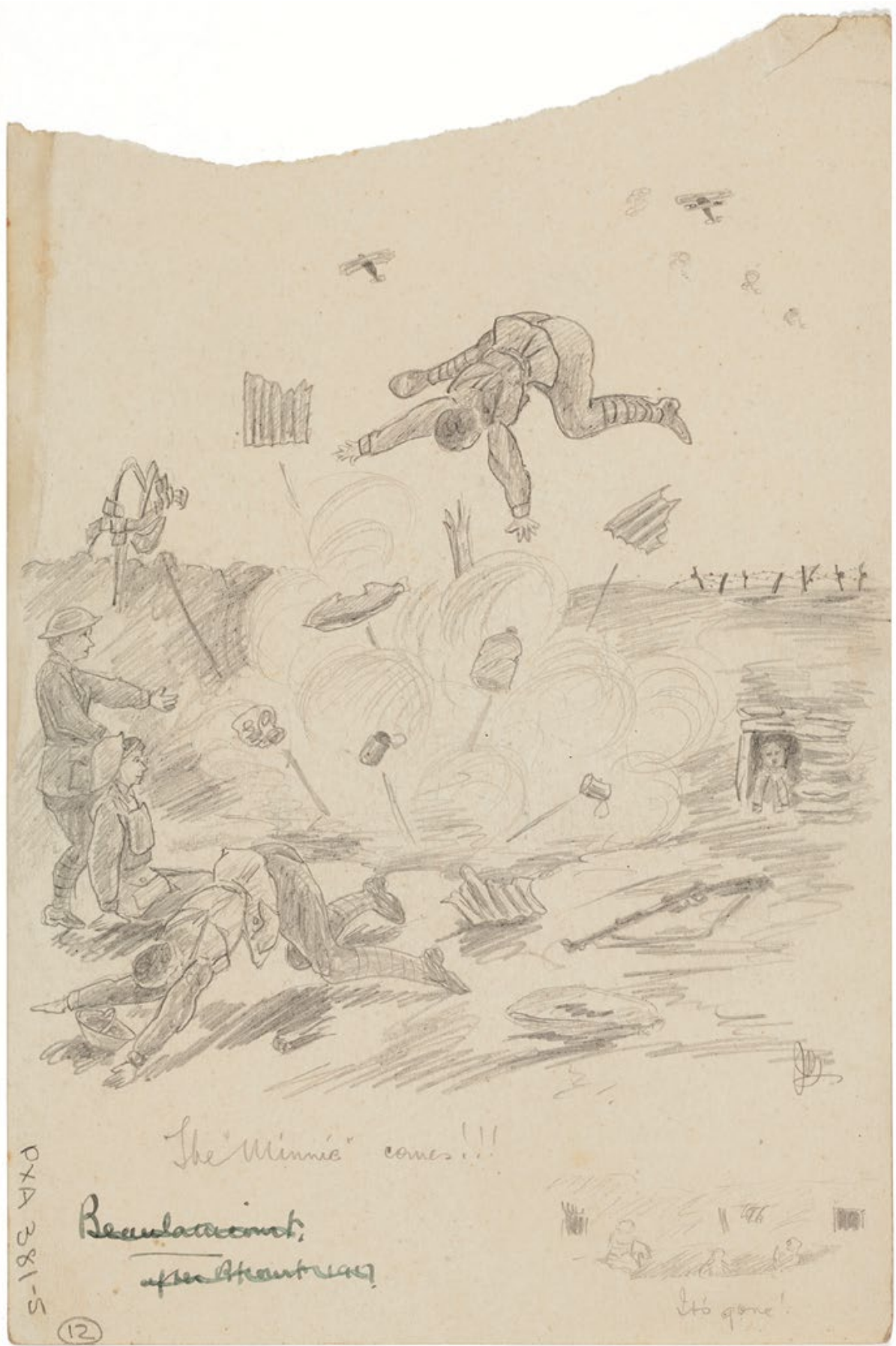

Figure 11: '12. The "Minnies" comes!!!' from James Marshall's Sketches of the Somme, 1917, 1917.

Source: State Library of New South Wales (SLNSW, PXA 381 (v. 2)). 


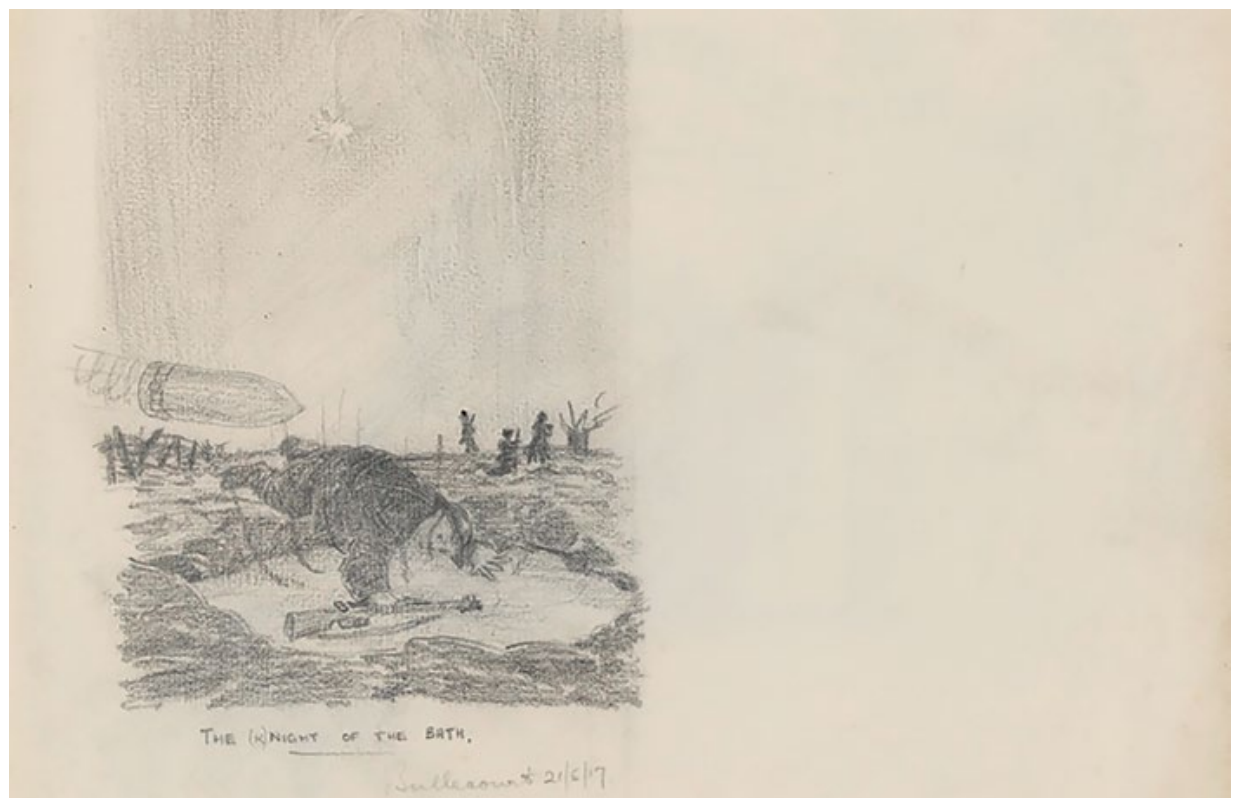

Figure 12: '33. The (K)night of the bath, Bullecourt, 21/5/17' from James Marshall's Sketches of the Somme, 1917, 1917. Source: State Library of New South Wales (SLNSW, PXA 381 (v. 2)).

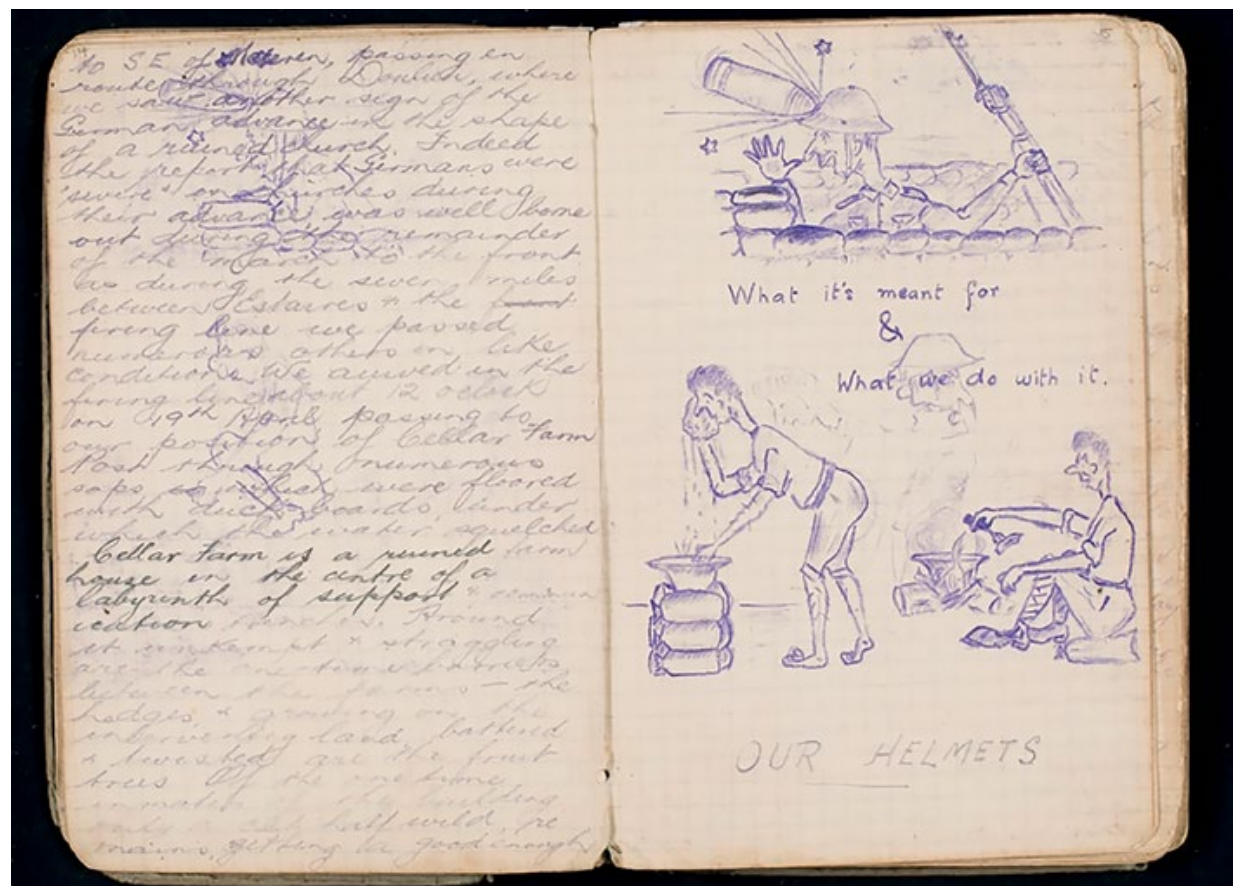

Figure 13: Page 10 of Robert Harris Diary, 24 July 1915-30 March 1916. Source: State Library of New South Wales (SLNSW, MLMSS 2773/3). 


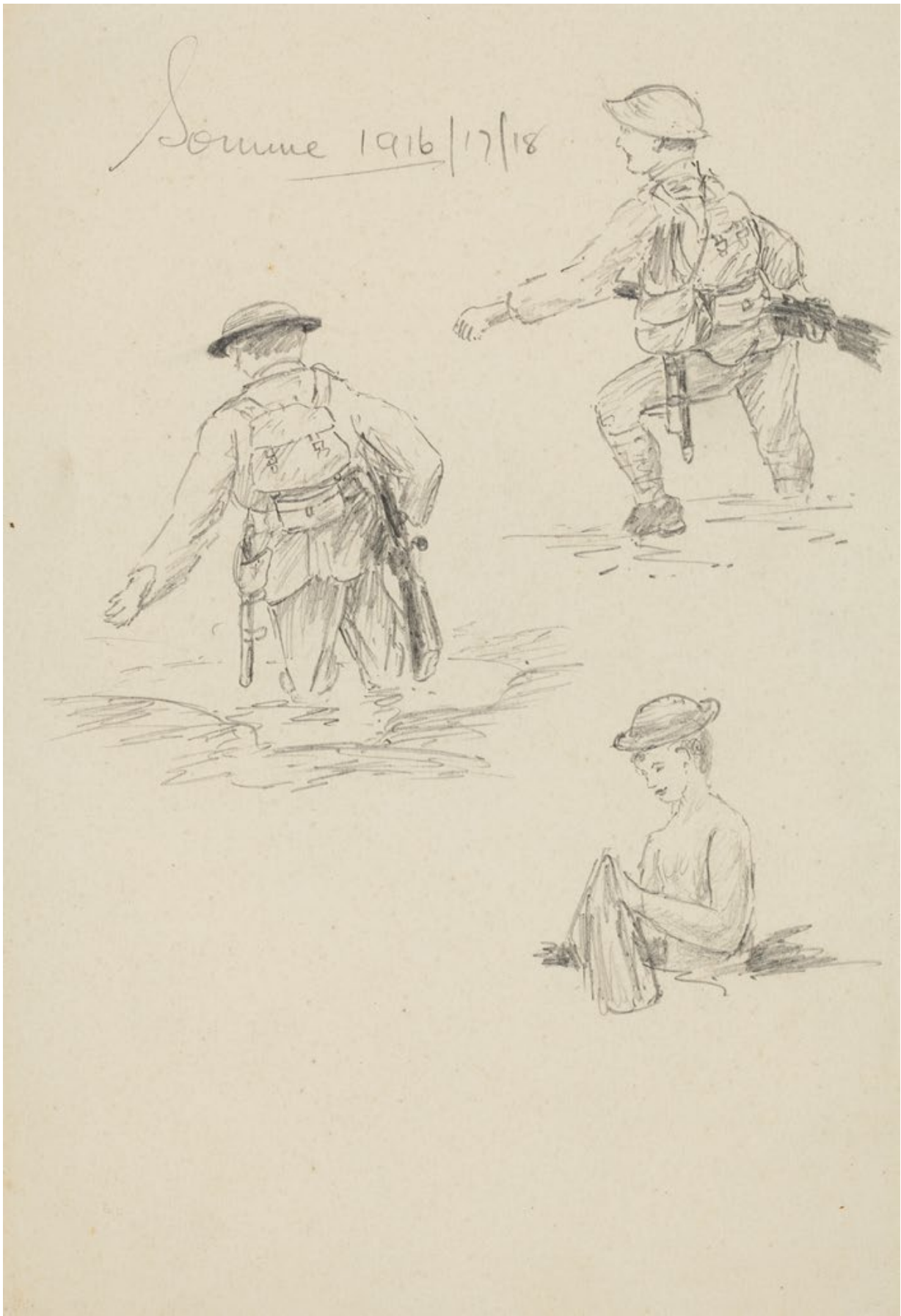

Figure 14: '14. Somme 1916/17/18' from James Marshall's Sketches of the Somme, 1917, 1917.

Source: State Library of New South Wales (SLNSW, PXA 381 (v. 2)). 


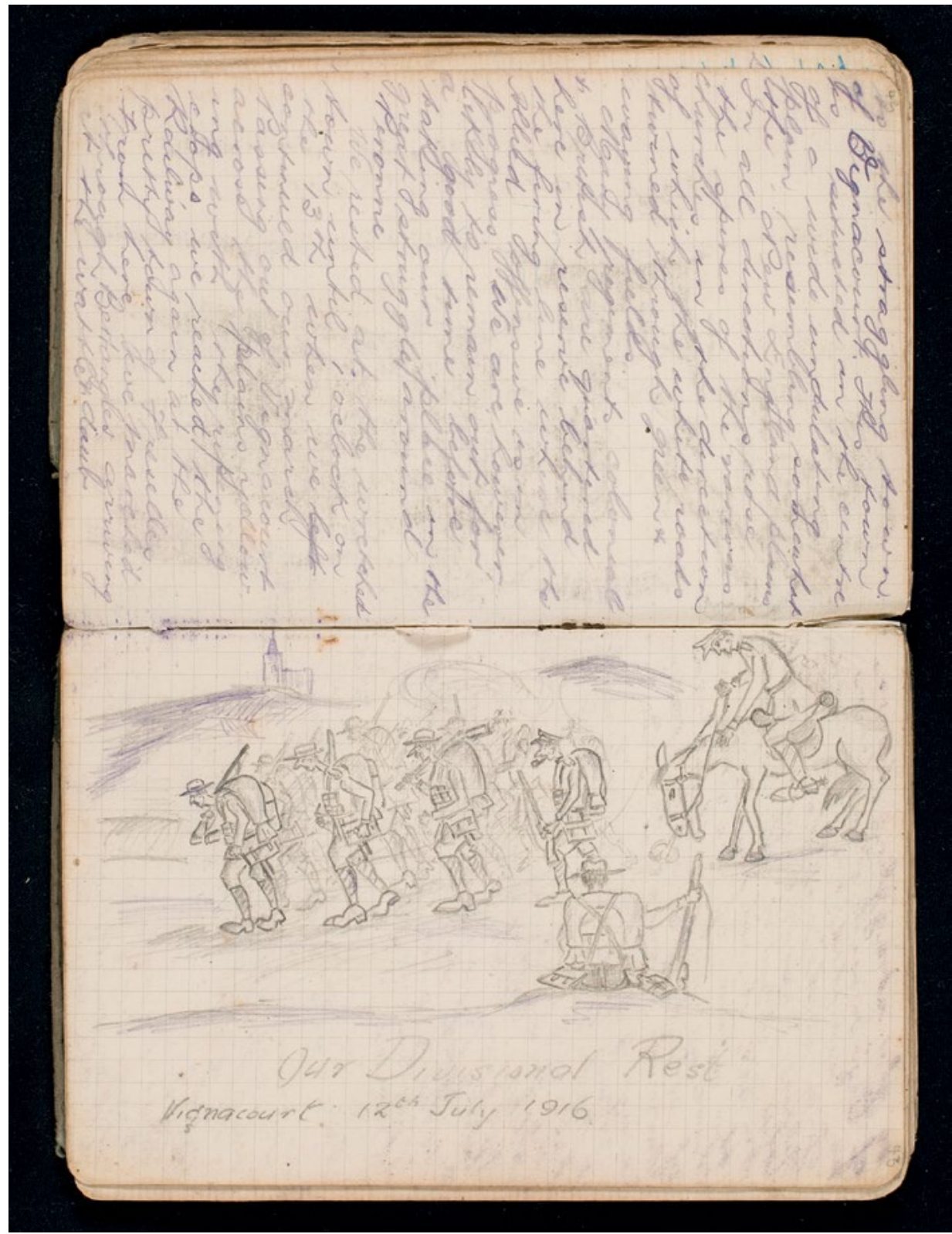

Figure 15: 'Our Divisional Rest' from Robert Harris Diary, 30 March 191628 March 1917.

Source: State Library of New South Wales (SLNSW, MLMSS 2773/3). 


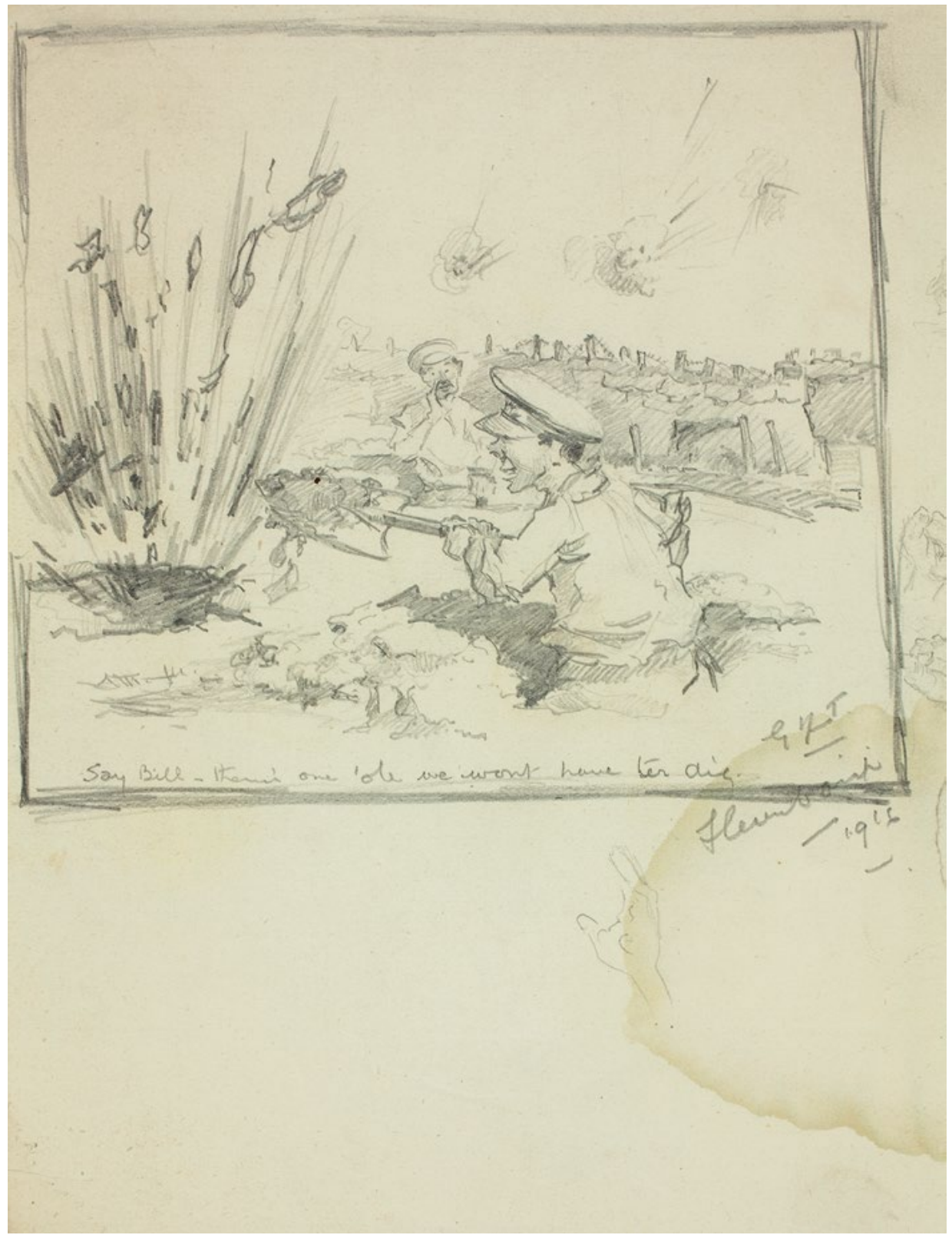

Figure 16: 'Say Bill - there's one 'ole we wont have to dig' from Geoffrey Keith Townshend War Sketches, 1916-19.

Source: State Library of New South Wales (SLNSW, PXA 383, 1916-1919). 


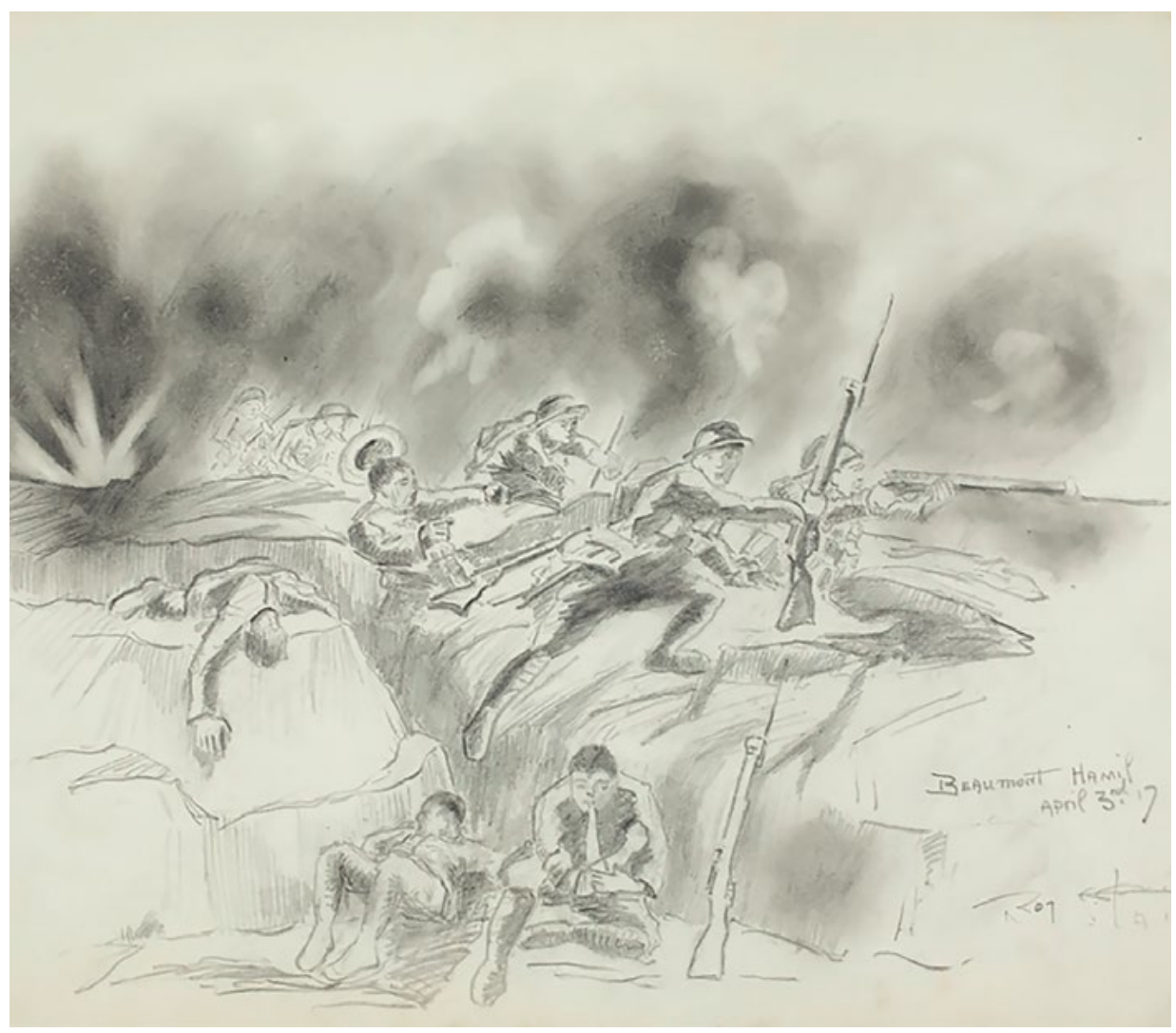

Figure 17: 'Beaumont Hamil, April 3rd 17' from Roy C. Jacob's Sketches of Warfare in World War I.

Source: State Library of New South Wales (SLNSW, PXE 714). 


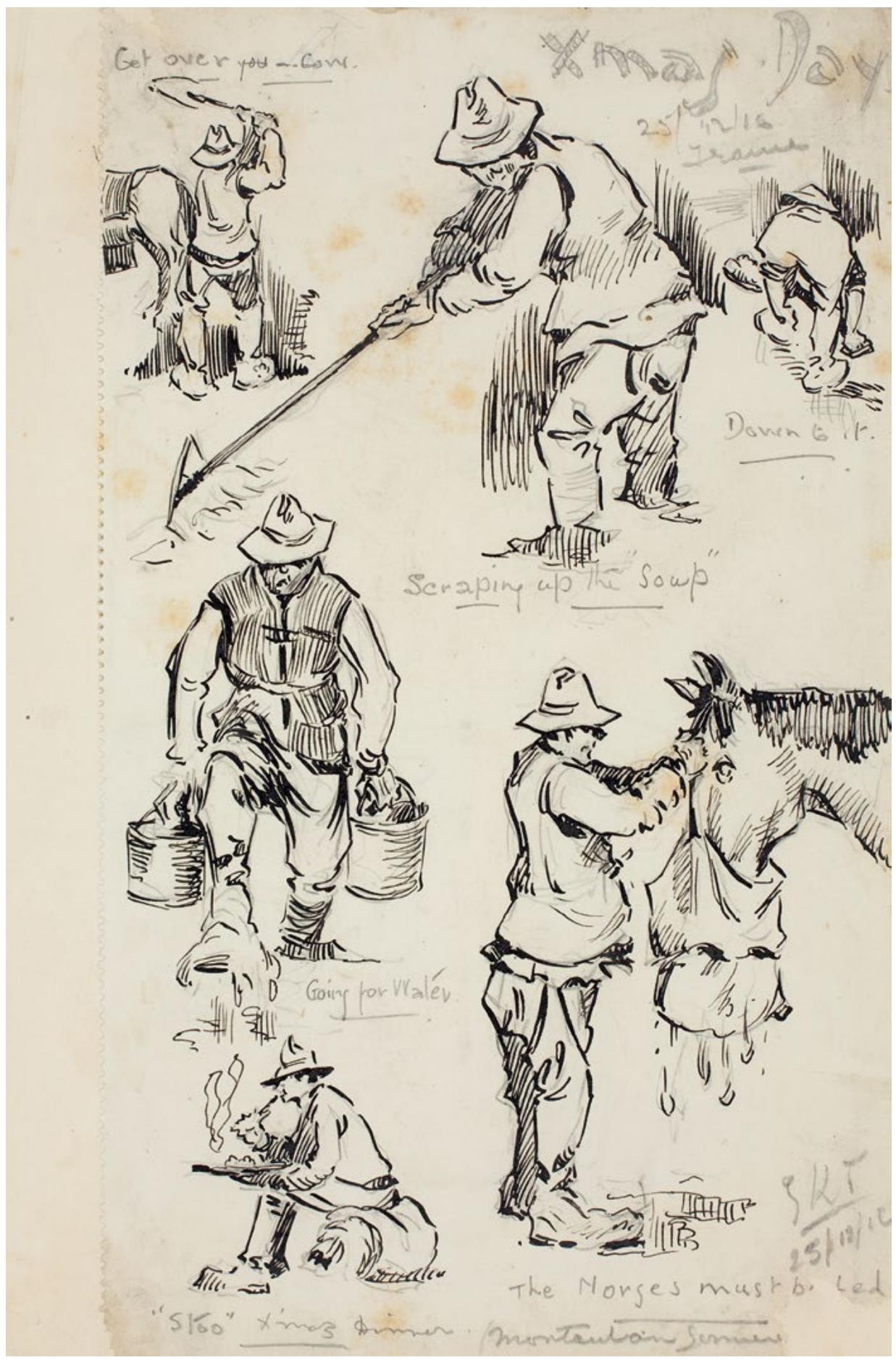

Figure 18: Page 61 of Geoffrey Keith Townshend War Sketches, 1916-19. Source: State Library of New South Wales (SLNSW, PXA 383, 1916-1919). 


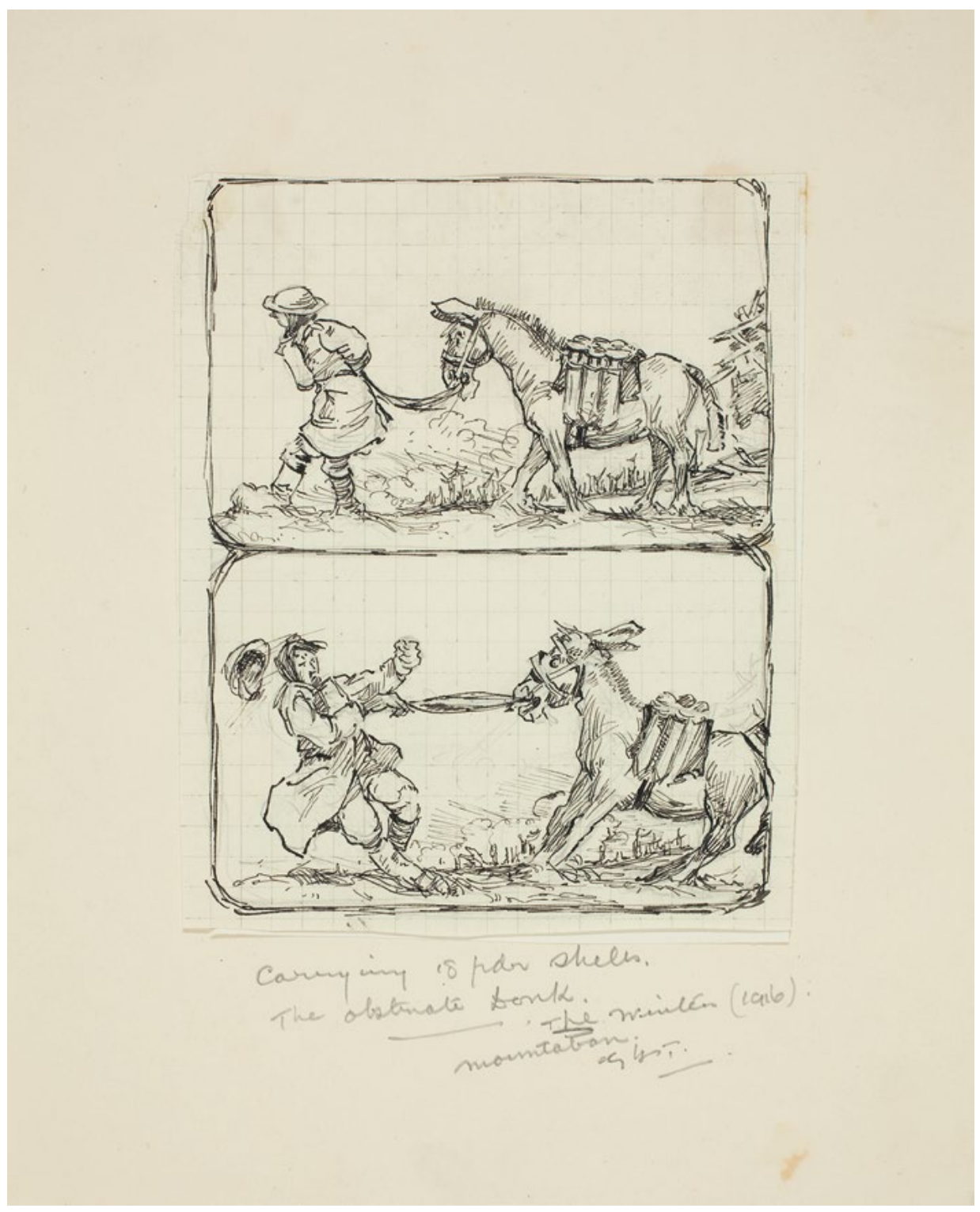

Figure 19: Page 75 of Geoffrey Keith Townshend War Sketches, 1916-19. Source: State Library of New South Wales (SLNSW, PXA 383, 1916-1919). 
The ANU Undergraduate Research Journal

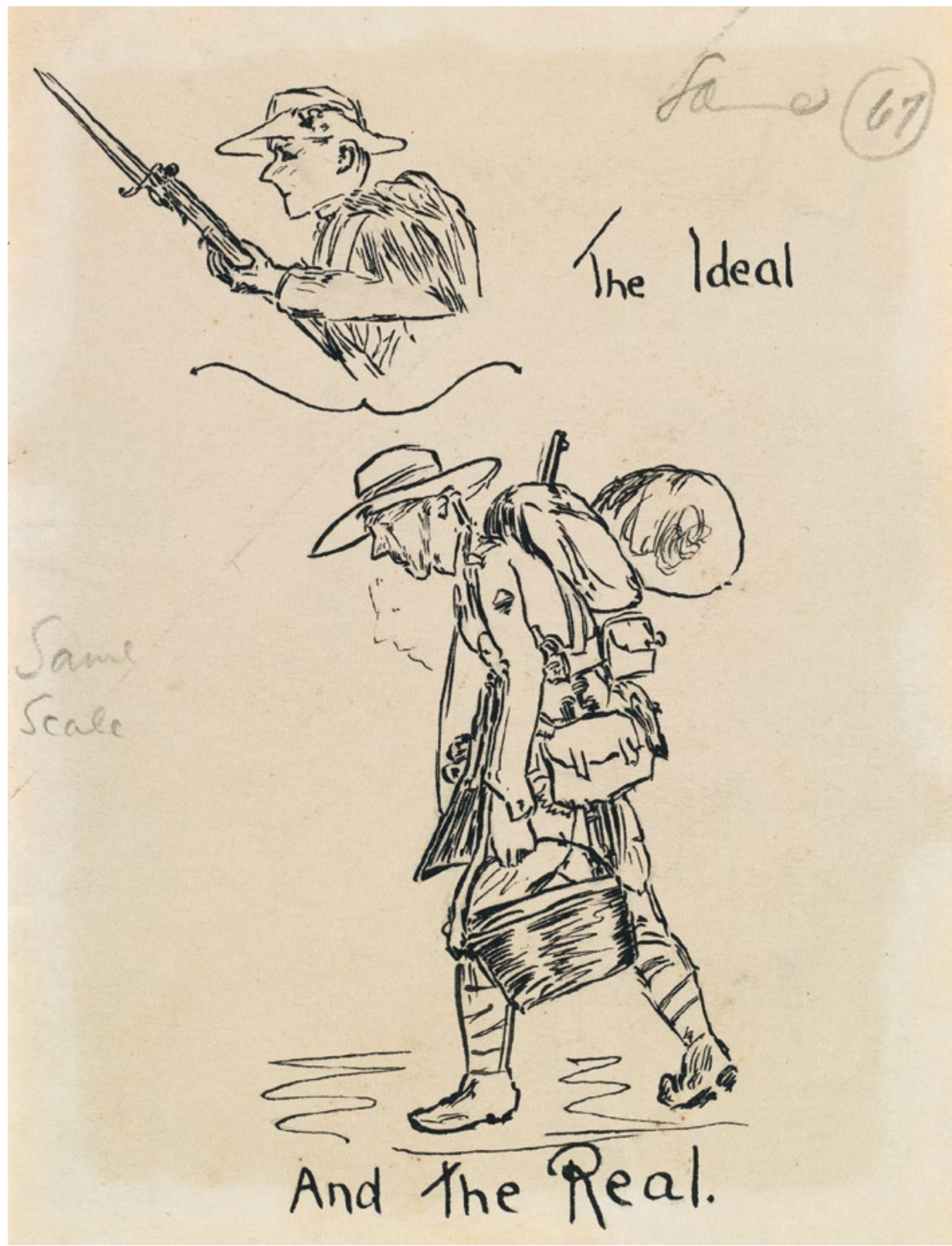

Figure 20: 'The ideal and the real' by Francis Page Hewkley, 1915 (later published in The Anzac Book).

Source: Australian War Memorial (AWM, ART00021.003).

56 


\section{Conclusion}

One of the most memorable soldiers' drawings from the First World War is Francis Hewkley's 'The real and the ideal', published in The Anzac Book in 1916 (Fig. 20). ${ }^{62}$ Hewkley's drawing typifies the way militaristic and 'working-man' masculinity were enacted by Australian soldiers in visual depictions of rifles and bayonets. The two weapons perform distinctively differently functions: the fixed bayonet serving as a symbol of aggression and martial prowess and the rifle retaining a passive quality that reaffirms the image of a working man. Recognising the coexistence of these two masculinities and examining the ways in which soldiers depicted rifles and bayonets in their drawings offers a new approach to the study of militaristic and 'workingman' masculinity. By understanding how the threat and use of weapons may be seen as part of 'doing' certain masculinities during wartime, this article presents a more nuanced understanding of how manliness and masculinity were enacted by soldiers themselves during the First World War.

\section{Bibliography}

\section{Primary sources}

\section{Drawings and sketchbooks}

Addison, Reginald H. 'not titled [Two soldiers sitting in a covered trench, near Hazebrouck]'. AWM, ART92338.015, 1918.

Dunbar, Ernst (actually John Beech). 'Dressed to Kill, Two Styles'. AWM, ART94463.017, 1918.

Dunbar, Ernst (actually John Beech). 'Mud!'. AWM, ART19520.003 (verso), $1914-18$.

Dunne, Lawrence Francis (Frank). 'Missed again'. AWM, ART12452, 1914-18.

Dunne, Lawrence Francis (Frank). 'Untitled'. AWM, ART12455, 1915-16.

Dunne, Lawrence Francis (Frank). 'Pull yourself together, man'. AWM, ART12448, $1915-18$.

Dunne, Lawrence Francis (Frank). 'You oughta try and 'ide that; yer might want it to sit on'. AWW, 12445, 1914-1918.

Eltham, William K. 'North flank, Sulva from Anzac'. AWM, ART00043, 1915.

62 Francis Paget Hewkley, 'The ideal and the real', 1915, AWM, ART00021.003. 
Gren, Niel A. Niel A. Gren World War I Sketches Collected by Miss A. A. N. Small. SLNSW, PXD 508/4-7, c. 1916.

Harris, Robert. Robert Harris Diary, 24 July 1915-30 March 1916. SLNSW, MLMSS 2773/2.

Harris, Robert. Robert Harris Diary, 30 March 1916-28 March 1917. SLNSW, MLMSS 2773/3.

Hewkley, Francis P. 'The ideal and the real'. AWM, ART00021.003, 1915.

Hore, Leslie. Sketches at Gallipoli, 1915. SLNSW, PXE 702, 1915.

Jacobs, Roy C. Sketches of Warfare in World War I. SLNSW, PXE 714, 1914-18.

Marshall, James J. Sketches of the Somme, 1917. SLNSW, PXA 381 (v. 2), 1917.

Marshall, James J. 2453 Pte. J. Marshall, 53rd Battalion H. Q., A.I.F., France. SLNSW, PXA 381 (v. 4), 1918.

Meldrum, Joseph B. 'not titled [Track and dump looking towards the front line]'. AWM, ART03192.009, 1917.

Price, Benjamin H. E. 'Our listening post was withdrawn'. AWM, ART94802, 1918

Stone, Alexander. 'Skit on a "better 'ole"'. AWM, ART03471, 1916.

Townshend, Geoffrey K. Geoffrey Keith Townshend War Sketches. SLNSW, PXA 383, 1916-19.

Walford, Dudley V. Dudley V. Walford Diary, 23 September 1914-13 August 1916. SLNSW, MLMSS 982/1.

Williamson, Garnet Angus. 'Aussie leaning on his rifle'. AWM, ART03573, 1914-18.

Music scripts

Dell, Evelyn and Frederick Gladdish. 'He was only a private-that's all'. Sydney, NSW: Albert \& Sons, 1915. NLA, 3310281.

Hadwen-Chandler, Herbert. 'To arms, Australia!'. Perth, WA: Dwyer \& Carroll, 1914-1918. SLWA, KDW/KM.

Mansfield, Alfred. 'Wake up! Australia'. Melbourne, VIC: Stanley Mullen Company, 1914. NLA, 2161143.

Morley, Arthur. 'Be a man, enlist to-day' (4th ed.). Melbourne, VIC: Dinsdales, 1914-1916. NLA, 133778. 
Rattray, Alan M. 'Don't forget Australia: You've got your mother's eyes on you'. Sydney, NSW: Albert and Son, c. 1916. NLA, 214568.

Talworth, Reginald de. 'Australia's brave soldiers: You're the one'. Sydney, NSW: Albert \& Son, c. 1916. NLA, 703321.

Woolmer, George. 'Soldiers of Australia'. Adelaide, SA: Cawthorne, 1914?. NLA, 2862377.

National Australian Archives (NAA)

Gould, Charles Henry (1552). Paper Files and Documents. NAA, B2455.

Leslie Fraser Standish Hore (?). Paper Files and Documents, NAA, B2455.

Marshall, James Joseph (2455). Service Record. NAA, B2455.

Townshend, Geoffrey Keith (11415). Paper Files and Documents. NAA, B2455.

Posters

Australia has promised Britain 50,000 more men. AWM, ARTV00021, 1915.

Don't stand looking at this: Go and help! NLA, ID2629777, c. 1915.

Lindsay, Norman \& W. A. Gullick Government Printers. The trumpet calls. AWM, ARTV00039, c. 1918.

Quick! Give us a hand old sport. AWM, ARTV08942, c. 1914-18.

Weston, Harry J. \& NSW Government and W. A. Gullick Government Printer. We took the Hill, come and help us keep it. AWM, ARTV00140, 1915.

\section{Secondary sources}

Australian War Memorial. (n.d.) 'Biography of "Captain Charles Henry Gould"'. Retrieved from www.awm.gov.au/people/P10678151/ (accessed 25 April 2016).

Australian War Memorial. (2010). The Anzac Book (3rd ed.). Sydney: University of New South Wales Press.

Blair, Dale James. (2001). Dinkum Diggers: An Australian Battalion at War. Carlton, Vic.: Melbourne University Press.

Bourke, Joanna. (1999). An Intimate History of Killing: Face-to-face Killing in Twentieth-Century Warfare. London: Granta Books. 
Budden, Frank M. (1973). The Mob: The Story of the 55/53rd Australian Infantry Battalion, A.I.F. Sydney: F.M. Budden.

Connell, R.W. (1987). Gender and Power: Society, the Person, and Sexual Politics. Cambridge: Polity Press \& B. Blackwell.

Costello, K.S.F. Edward. (1841). The Adventure of a Soldier; of, Memoirs of Edward Costello, K.S.F. London: Henry Colburn.

Crotty, Martin. (1999). 'Heroes of Australia: Race, Nation and Masculinity in Australian Boys' Adventure Stories, 1875-1920'. Bulletin (Olive Pink Society), $11(1-2), 22-27$.

Crotty, Martin. (2001). Making the Australian Male: Middle-Class Masculinity 1870-1920. Melbourne: Melbourne University Press.

Dauge, Everett \& Tucker, Spencer C. (2014). 'Bayonets'. In Spencer C. Tucker. (ed.), World War I: The Definitive Encyclopedia and Document Collection. Santa Barbara, California: ABC-CLIO.

Dwyer, Bryan. (1997). 'Place and Masculinity in the Anzac Legend'. Journal for the Association of the Study of Australian Literature, 4, 226-31.

Engen, Rob. (2006). 'Steel against Fire: The Bayonet in the First World War'. Journal of Military and Strategic Studies, 8(3), 1-23.

Externalisation. (n.d.). Oxford Dictionary of English (3rd ed.). Retrieved from en.oxforddictionaries.com/definition/externalize.

Fawcett, Robert. (1977). On the Art of Drawing: An Informal Textbook with Illustrations by the Author. New York: Watson-Guptill Publications.

Gammage, Bill. (1992). 'Anzac'. In John Carroll (ed.), Intruders in the Bush: The Australian Quest for Identity, 54-66. Oxford: Oxford University Press.

Gammage, Bill. (1982). The Broken Years: Australian Soldiers in the Great War. Ringwood, Vic.: Penguin Books.

Garton,Stephen.(1998). 'Warand Masculinityin Twentieth CenturyAustralia'.Journal of Australian Studies, 22(56), 86-95. doi.org/10.1080/14443059809387363

Goldschmidt, Gabriela. (2004). 'Design Representation: Private Process, Public Image'. In Gabriela Goldschmidt and William L. Porter (eds), Design Representation, 203-18. London: Springer-Verlag. doi.org/10.1007/b97667

Grossman, Dave. (1995). On Killing: The Psychological Cost of Learning to Kill in War and Society. Boston: Little Brown. 
Hodges, Paul. (2008). 'They Don't Like It up 'Em!: Bayonet Fetishization in the British Army During the First World War'. Journal of War \& Culture Studies, 1(2). doi.org/10.1386/jwcs.1.2.123_1

Knowles, Fred. (1918). With the Dinkums (Vol. I). Sydney: NSW Bookstall Co. Ltd.

Kuring, Ian. (2009). 'Small Arms in Australian Service'. In Peter Dennis, Jeffrey Grey, Ewan Morris, Robin Prior and Jean Bou (eds), The Oxford Companion to Australian Military History. Oxford: Oxford University Press.

Lake, Marilyn. (2004). 'Translating Needs into Rights: The Discursive Imperative of the Australian White Man, 1901-30'. In Stefan Dudink, Karen Hagemann and Josh Tosh (eds), Masculinities in Politics and War: Gendering Modern History, 119-219. Manchester: Manchester United Press..

Lithgow Small Arms Factory. (n.d.). 'Military Production at Lithgow Saf: .303 Short Magazine Lee Enfield (SMLE) Rifle No 1 MkIII and MkIII* Complete with Bayonet'. Retrieved from www.lithgowsafmuseum.org.au/milproduction.html

Maynard, Patrick. (2005). 'Review'. In David Rosand (ed.), Drawing Acts: Studies in Graphic Expression and Representation, 81-83. Cambridge: Cambridge University Press.

McQuilton, John. (2000). Journal of the Australian War Memorial, 33. Retrieved from www.awm.gov.au/journal/j33/mcquilton/

Murphy, Kate. (2008). 'The "Most Dependable Element of Any Country's Manhood": Masculinity and Rurality in the Great War and Its Aftermath'. History Australia, 5(3), 72.1-72.20.

Myrttinen, Henri. (2004). "'Pack Your Heat and Work the Streets"-Weapons and the Active Construction of Violent Masculinities'. Women and Language, 27(2), 29-34.

Myrttinen, Henri. (2003). 'Disarming Masculinities'. Women, Men, Peace and Security, 4, 37-46.

O'Leary, Capt Michael M.(1999). 'A La Bayonet, or, "Hot Blood and Cold Steel”'. Journal of Non-lethal Combatives, November.

Pegram, Aaron. (2009). 'The Spirit of the Bayonet'. Wartime, 47, 49-53.

Phillips, Richard. (1997). Mapping Men and Empire: A Geography of Adventure. London: Routledge.

Reynolds, Edmund George Barton. (1960). The Lee-Enfield Rifle. London: Herbert Jenkins. 
Reynolds, Henry. (2010). 'Are Nations Really Made in War?'. In Marilyn Lake and Henry Reynolds (eds), What's Wrong with Anzac? The Militarisation of Australian History, 24-44. Sydney: University of New South Wales.

Rosand, David. (2002). Drawing Acts: Studies in Graphic Expression and Representation. New York: Cambridge University Press.

Scott, Ernest. (1941). 'Volume XI-Australia During the War'. In Charles Bean (ed.), Official History of Australia in the War of 1914-1918, 874. Canberra: Australian War Memorial.

Stone, John. (2012). 'The Point of the Bayonet'. Technology and Culture, 53(4), 885-908. doi.org/10.1353/tech.2012.0149

Sussman, Herbert. (2012). Masculine Identities: The History and Meanings of Manliness. California: ABC-CLIO.

Sutcliffe, Marcella P. (2016). 'Reading at the Front: Books and Soldiers in the First World War'. International Journal of the History of Education, 52(1-2), 104-120. doi.org/10.1080/00309230.2015.1133671

Tversky, Barbara. (1999). 'What Does Drawing Reveal About Thinking?'. In J.S. Gero and B. Tversky (eds), Visual and Spatial Reasoning in Design, 93-101. Sydney: Key Centre of Design Computing and Cognition.

Ward, Russel. (1956). 'The Ethos and Influence of the Australian Pastoral Worker'. $\mathrm{PhD}$ thesis. Canberra: The Australian National University.

Wise, Nathan. (2014). Anzac Labour: Workplace Cultures in the Australian Imperial Force During the First World War. New York: Palgrave Macmillan. doi. org/10.1057/9781137363985

Woodward, Rachel. (2000). 'Warrior Heroes and Little Green Men: Soldiers, Military Training, and the Construction of Rural Masculinities'. Rural Sociological Society, 65(4), 640-57. doi.org/10.1111/j.1549-0831.2000.tb00048.x 
This text is taken from The ANU Undergraduate Research Journal, Volume Eight, 2016, edited by Daniel McKay, published 2017 by ANU eView, The Australian National University, Canberra, Australia.

dx.doi.org/10.22459/AURJ.08.2016.05 